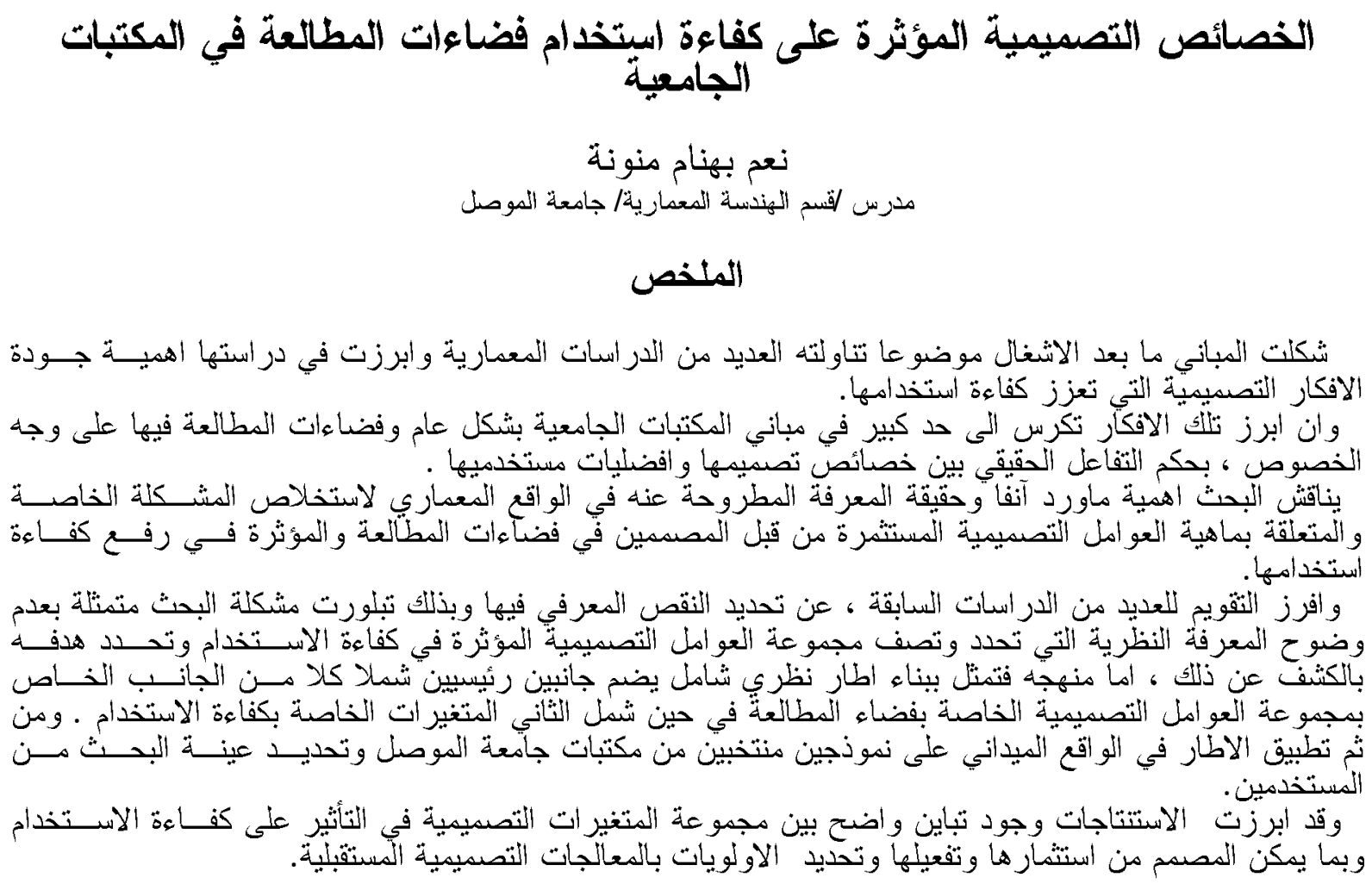

\title{
Design characteristics that affect usage efficiency of reading spaces in University Libraries
}

\author{
Niam Behnam Manona \\ Department of Architecture /University of mosul
}

\begin{abstract}
Post occupated buildings have formed a subject examined by several architectural studies and arose in their concluion the importance of suitable designing concepts that promote the efficiency of its use arose these ideas into light was greatly envisaged in the university libraries' buildings in general and their reading spaces in particular, which dominate real interaction among their designing characteristics and users' preferences. The research discusses the significance of what have been mentioned above and the reality of knowledge related to it in the architectural reality to extract the special problem related to the designing factors that are invested by designers in reading spaces which have an influence on increasing their use efficiency.

Evaluation of several previous studies has led to identifying knowledge deficiency and thus the research problem was represented by unclear theoretical knowledge which determines and describes the set of the affecting designing factors in the usage efficiency and determining its aim by revealing it. As to its methodology; it was represented by building up a theoretical framework included two major aspects one of which discusses the designing factors regarding the reading space; whereas the second includes the variables regarding the usage efficiency. Then the theoretical framework was applied in the field aspect on selected models from the libraries of the university of Mosul and determining the research population among users.

Conclusions have shown an evident variation between the effect of the designing factors on the use efficiency such that enable the designer investing, activating and determining the priorities of future designing treatments.
\end{abstract}

Keyword: Usage efficiency of building . 


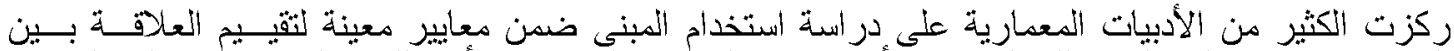

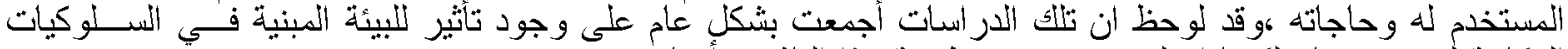

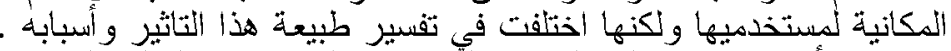

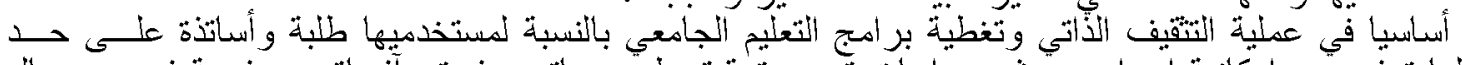

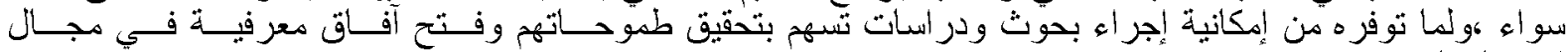

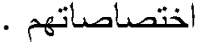

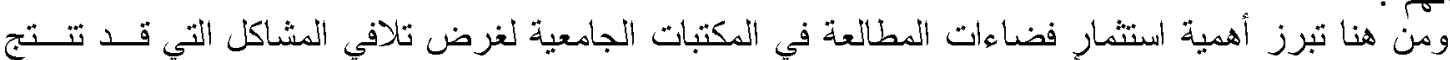

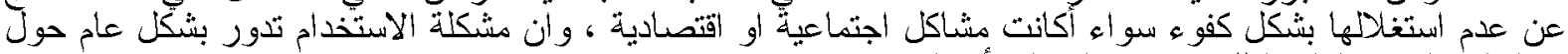

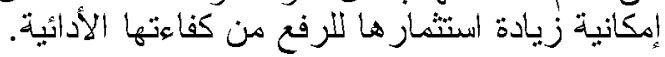

\section{1 - أهمية الموضوع}

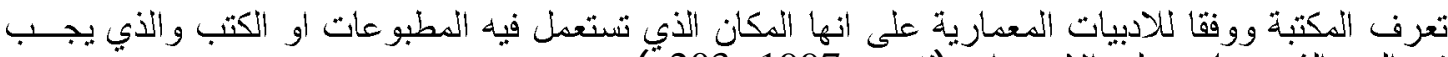

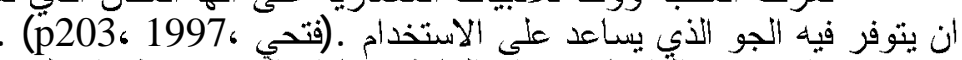

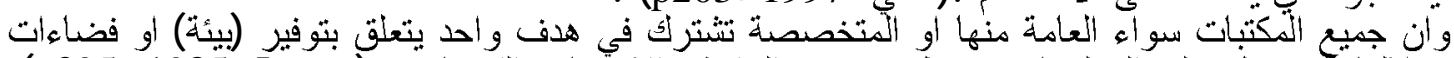

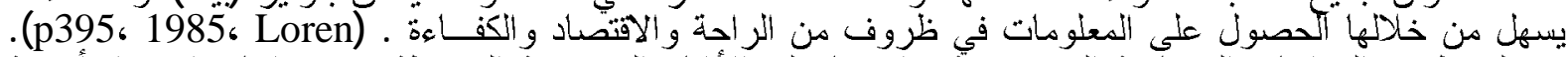

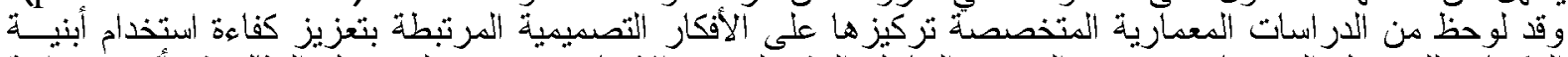

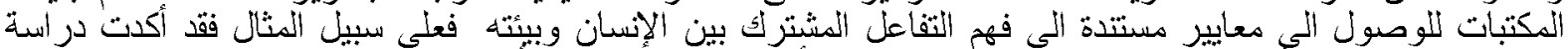

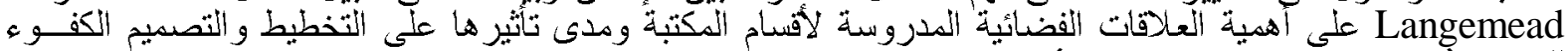

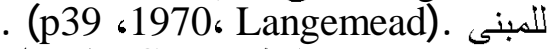

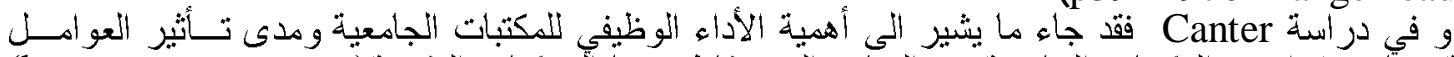

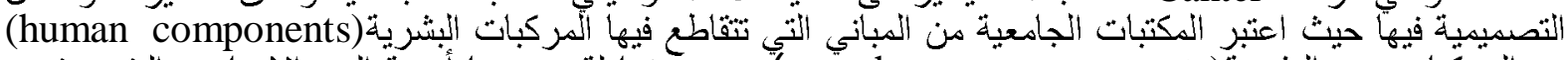

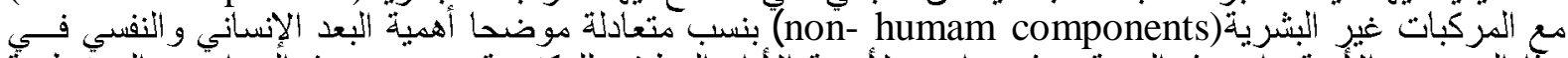

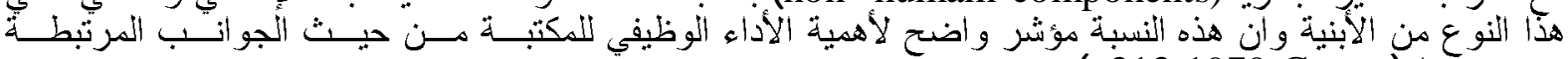

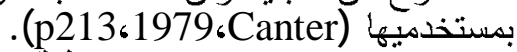

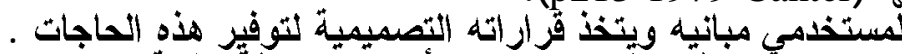

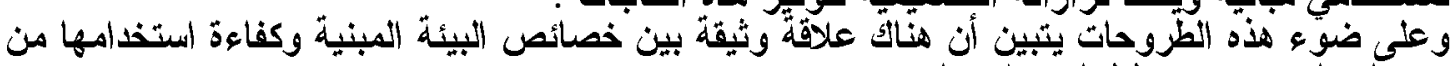

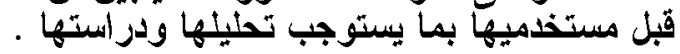

\section{2 - المثكية الخاصة / الو اقع المعماري}

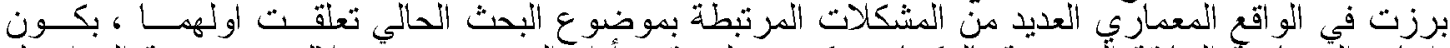

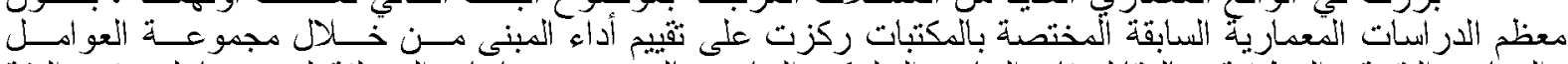
و والمعايير التقنية و الوظيفية وبالمقابل فان الجانب النسلوكي الخاص بالمستخدم وحاجاته المختلفة لم يتم تتاوله بنفس الدقة الته امأ المشكلة الثثنية فارتبطت بثقاطع وجهات النظر الخاصـة بتحديد مجموعة العو امل التصميمية المــؤثرة فـي و التفصيل .

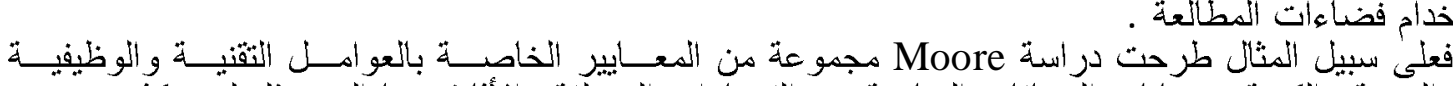

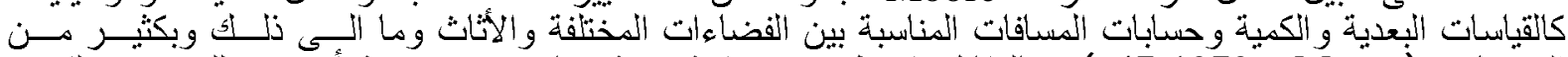

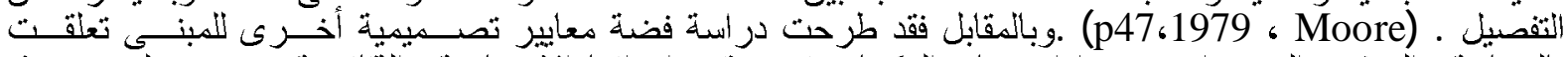

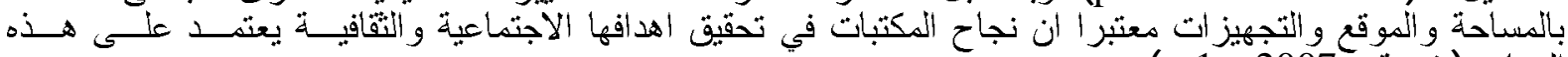

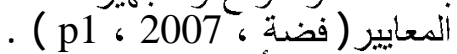

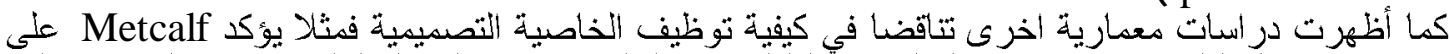

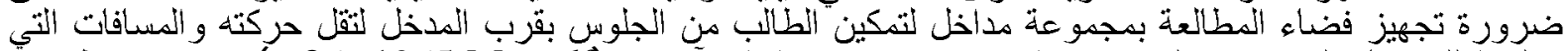

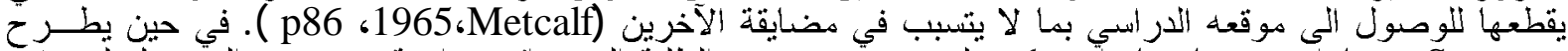

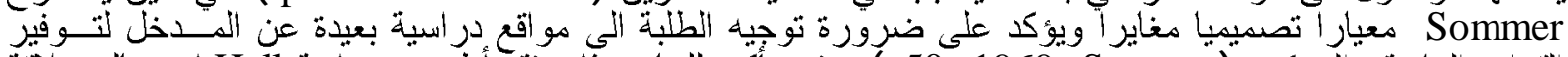

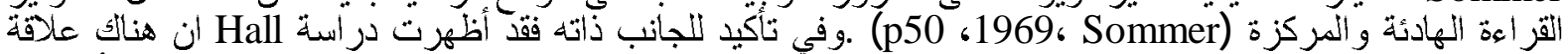

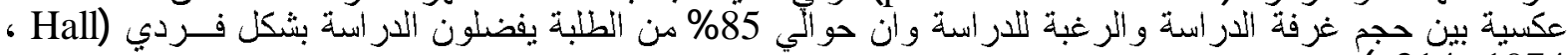
(p214، 1974

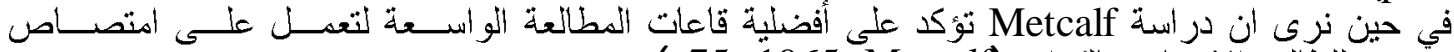

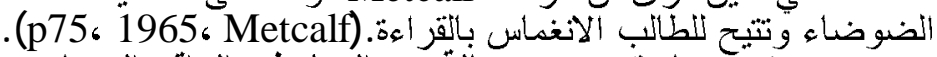

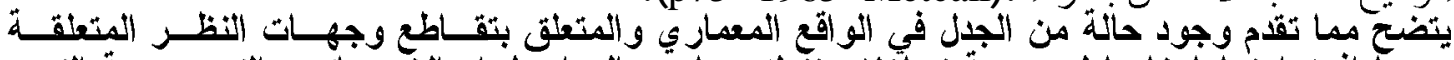

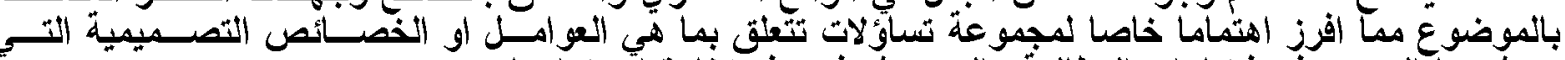

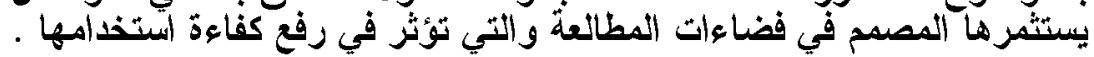




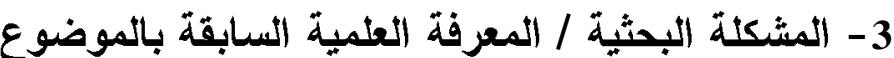

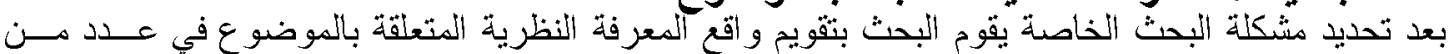

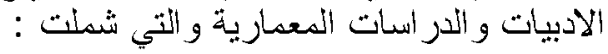

1-3 1-3 الار اسات العامة

1979 /Robinbowitz 1-3 1-3 دراسة 1-12

تعد در اسة Robinbowitz من الار اسات العامة والتي تتاولت في فحو اها مفهوم تقيبم المباني ما بعد الأشغال

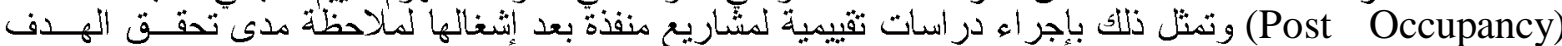

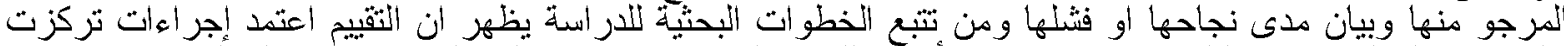

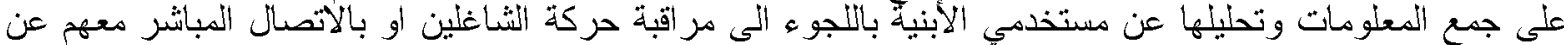

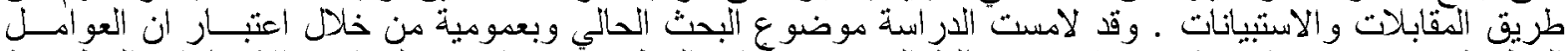

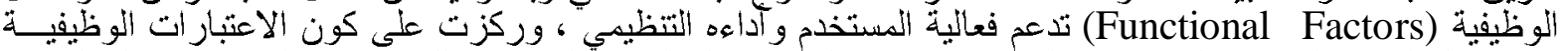

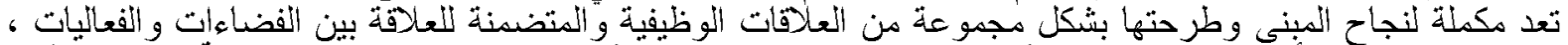

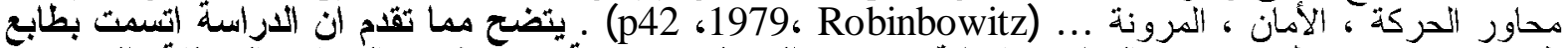

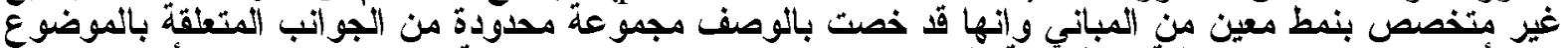

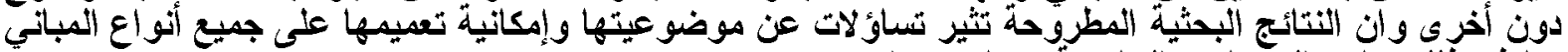

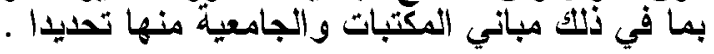

2007 / 2-3

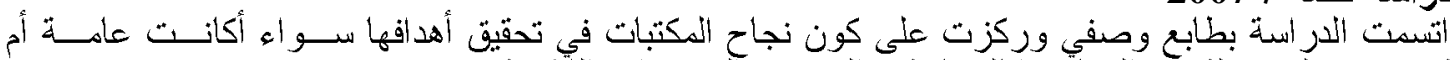

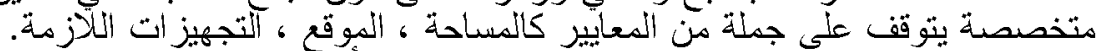

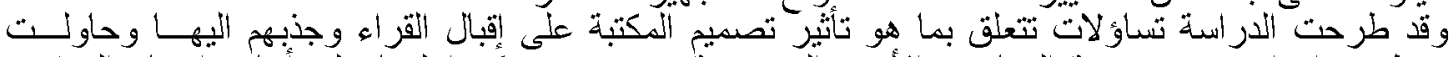

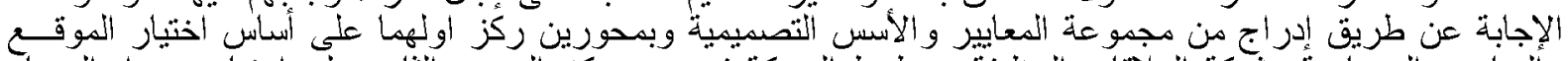

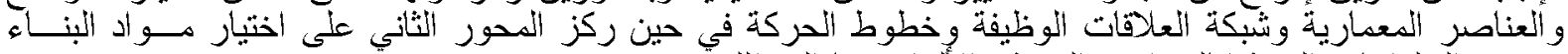

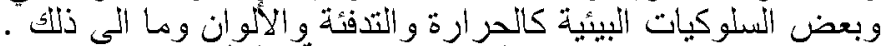

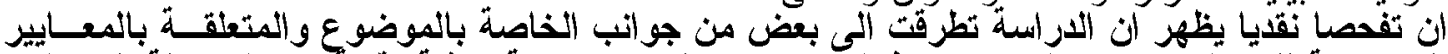

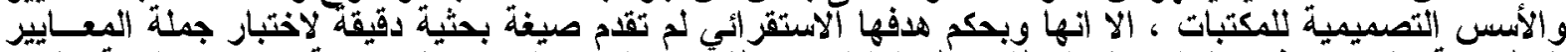

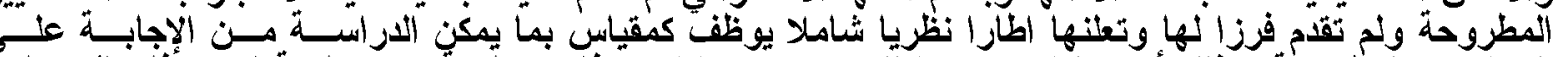

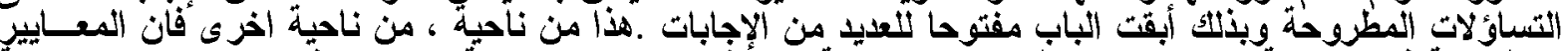

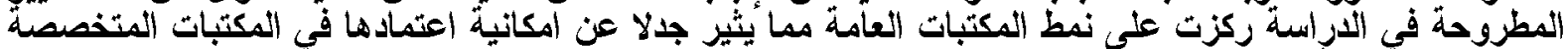

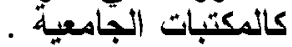

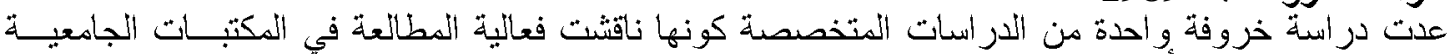

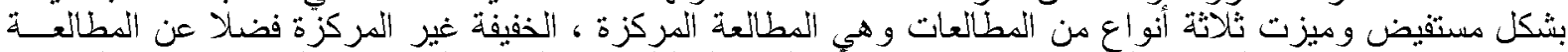

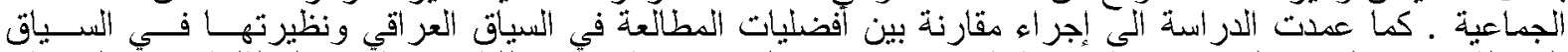

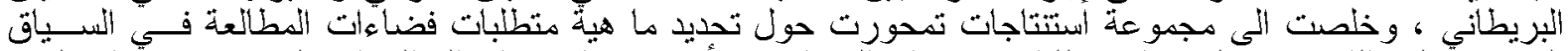

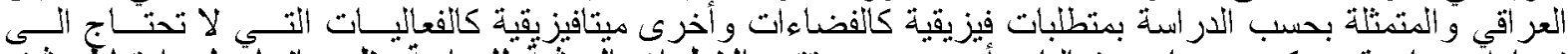

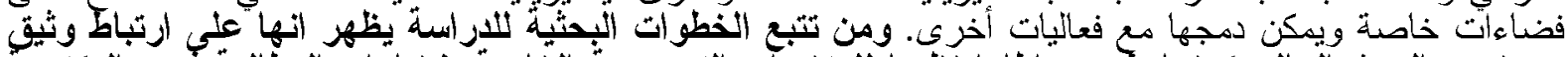

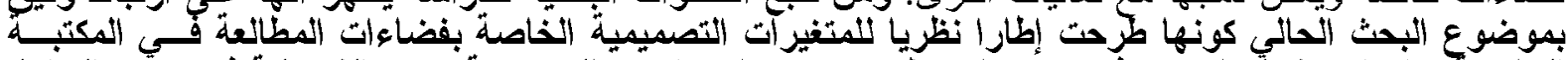

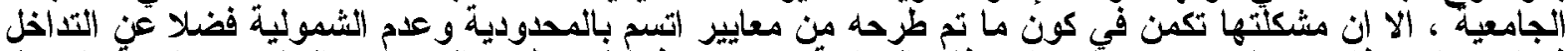

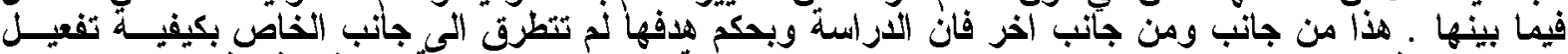

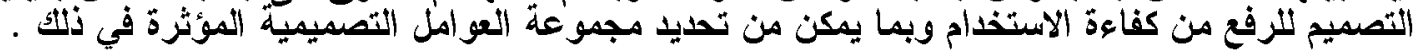

1994 / 2-3 199

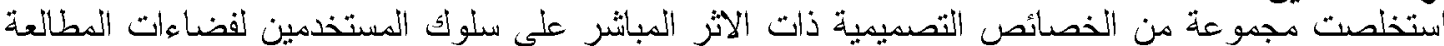

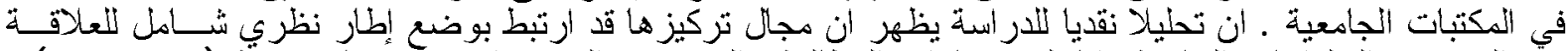

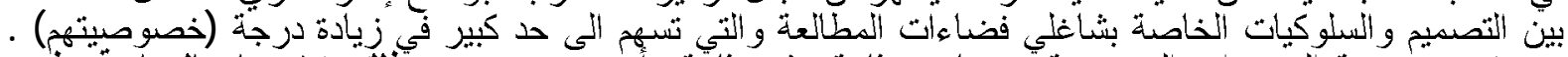

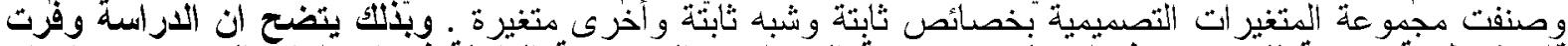

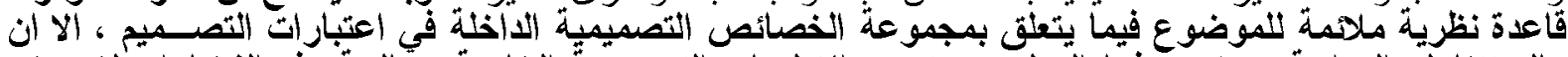

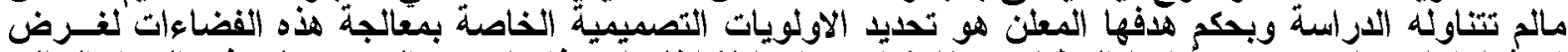

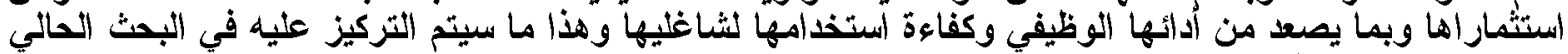

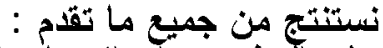

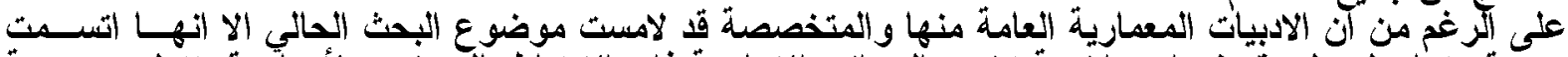

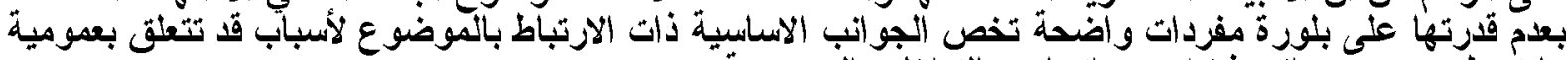

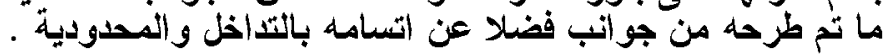



Al-Rafidain Engineering
Vol.19
No.1
February 2011

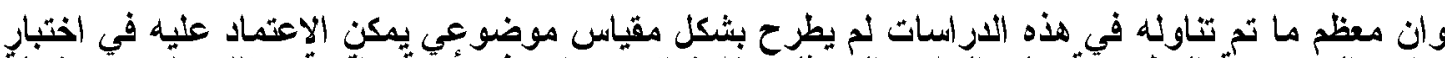

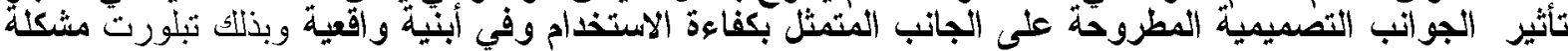

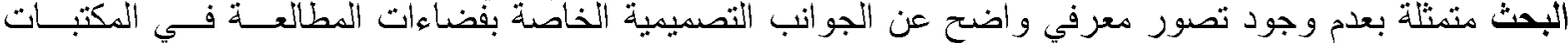

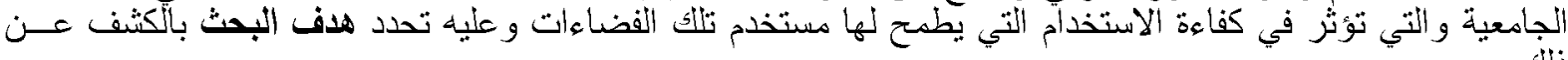

كما ويفترض البحث ان العلاقات بين الجو انب التصميمية وكفاءة الاستخدام موجودة في الأبنية الو اقعية ؛ امسا

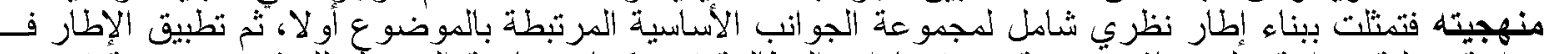

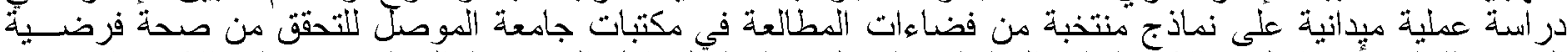

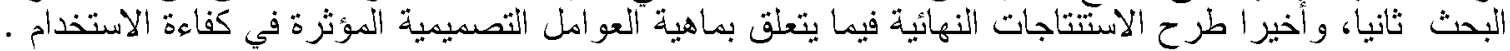

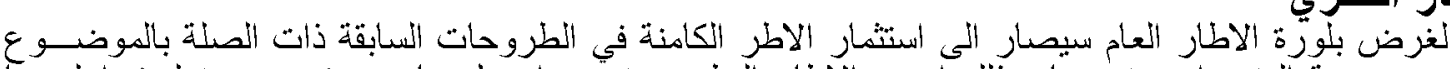
4

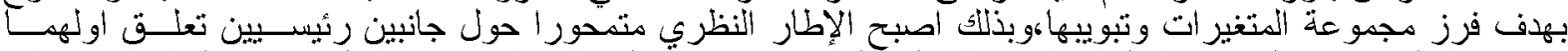

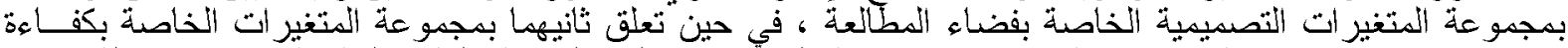

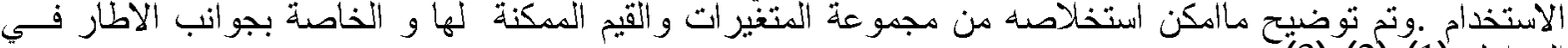
الجداول (1)،(2)،(3). (3).

1-4 الجانب الأول / المتغيرات التصميمية الخاصة بفضاءئات المطالعة

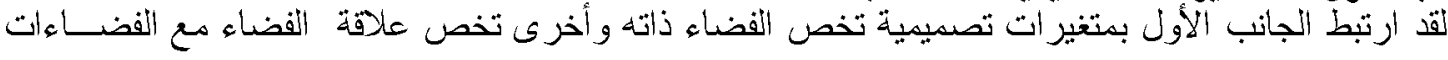

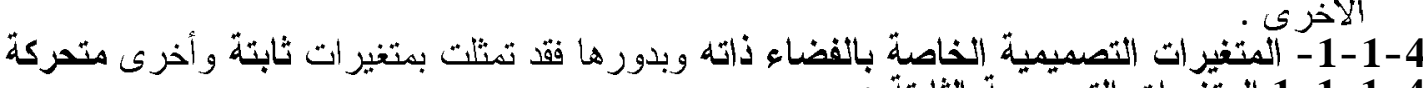
1-1-1-4 المتفيرات التصميمية الثيابتة

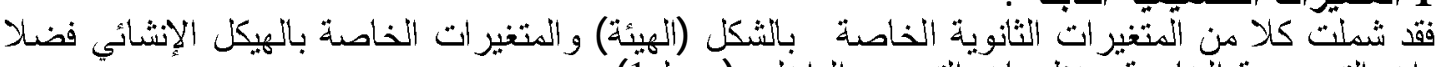

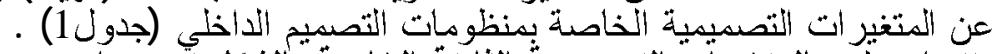

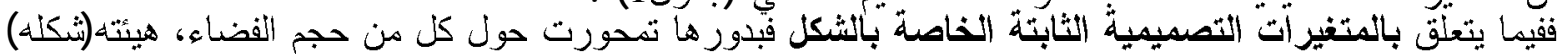

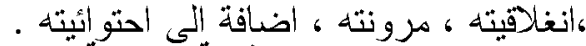

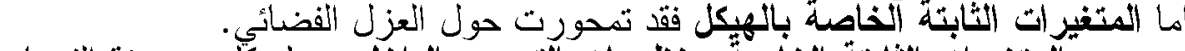

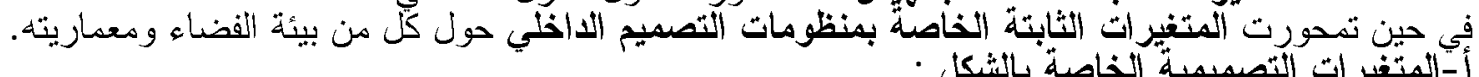

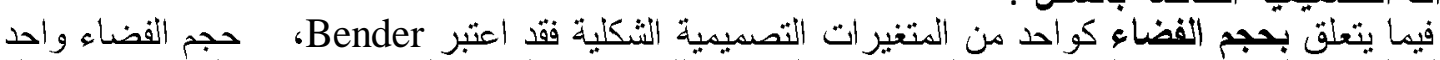

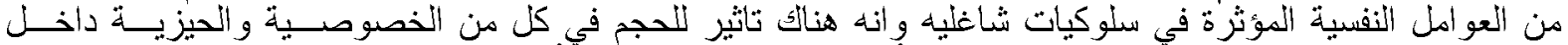

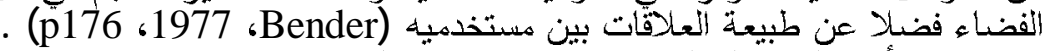

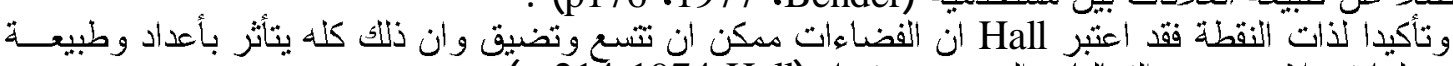

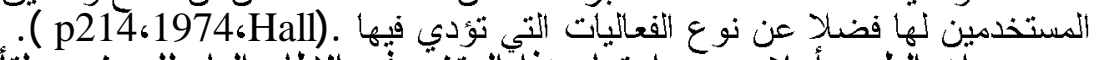

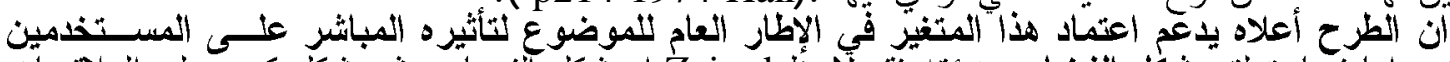

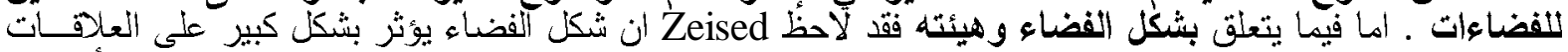

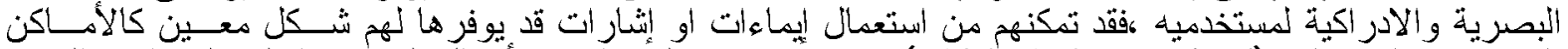

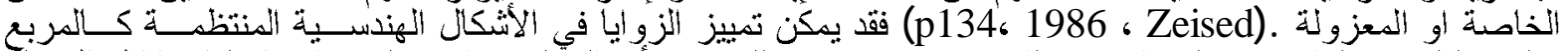

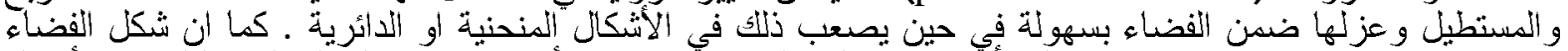

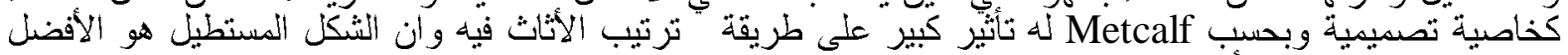

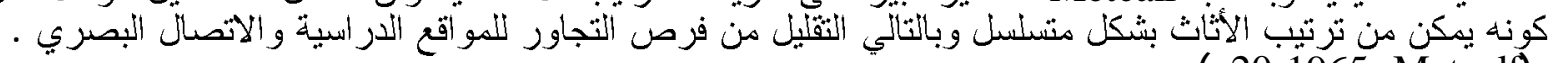
.(p2061965، Metcalf)

ان ما يظرح اعلاه يدعم الهية هذا المتغير و امكانية اختباره في الدزاسة العملية .

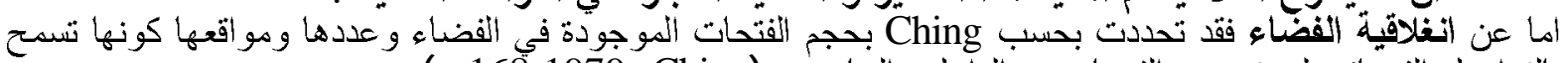

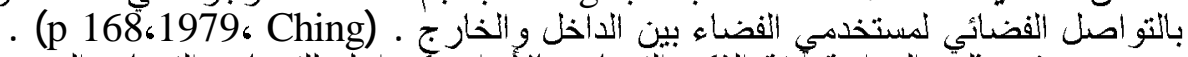

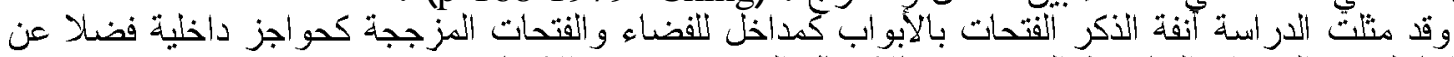

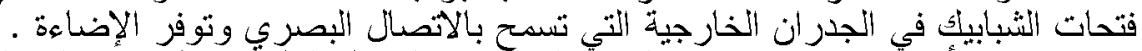

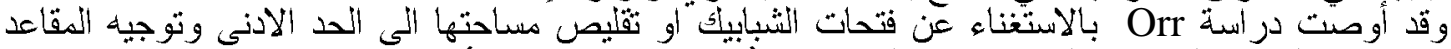

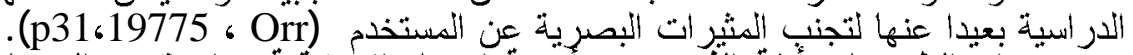

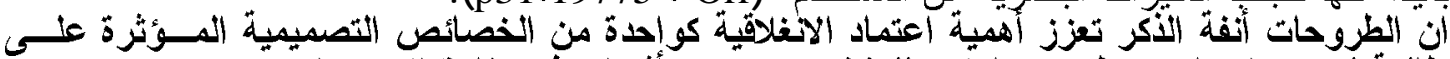

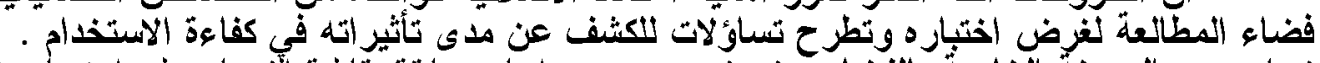

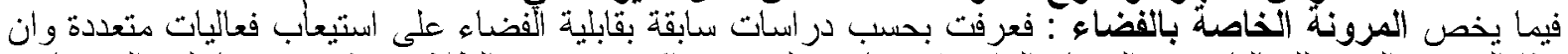

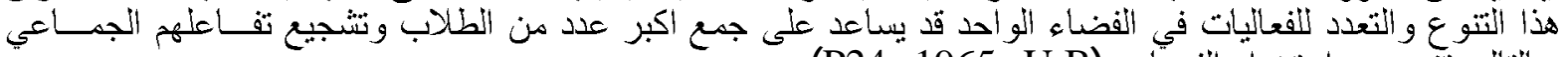

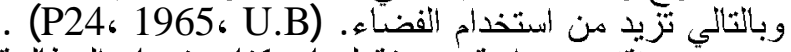

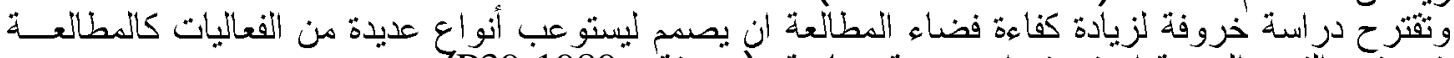
و الألعاب في نفس الفترة الزمنية او في فتر ات زمنية هتناوبة. (خروفة ، "P39،1989) . 
منونة: الذصائص التصميمية المؤثرة على كفاعة استخدام فضاءات المطالعة في المكتبات الجامعية

يتبينين من المدلاحظات أعلاد مدى الأهمية المتحققة هن مرونة الفضاء لتحقيق الاستخدام الأفضل وبالتـالي

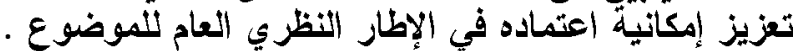

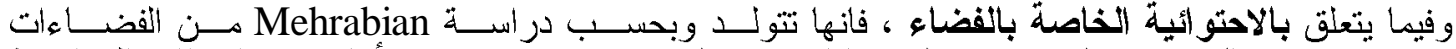

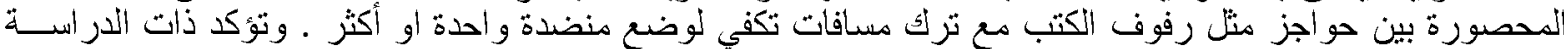

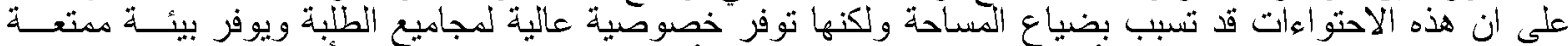

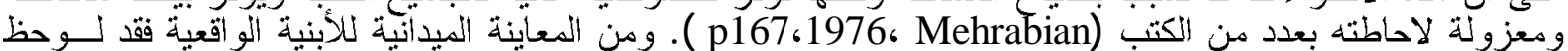

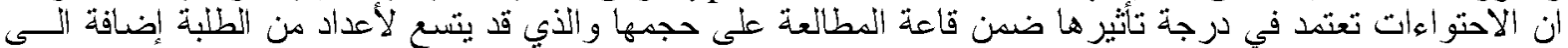

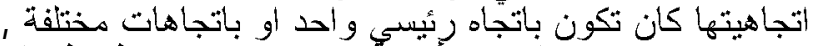

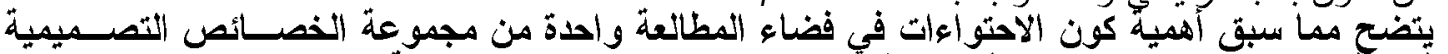

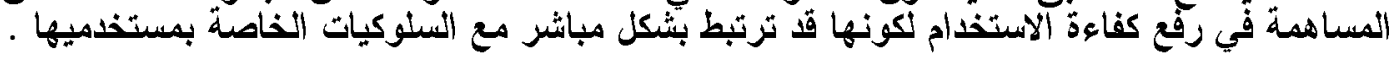

ب - المتفير ات التصميمية الخاصة بالهيكل:

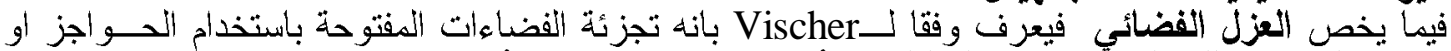

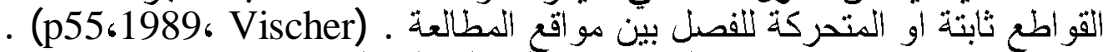

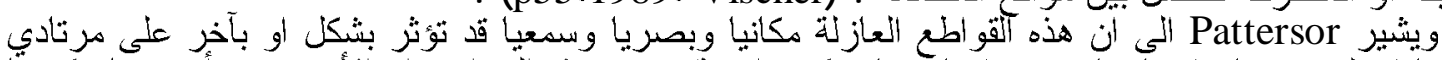

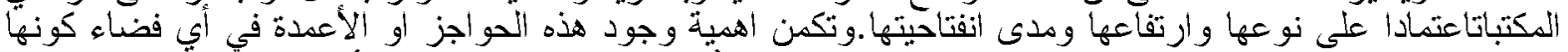

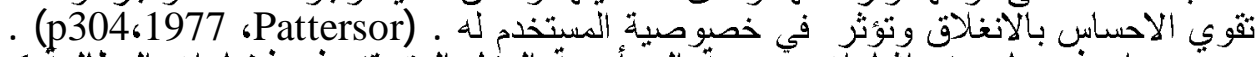

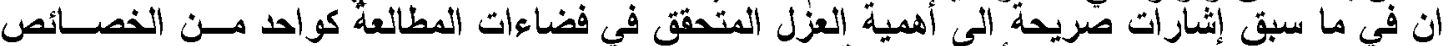

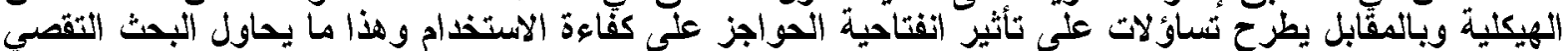

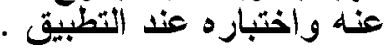

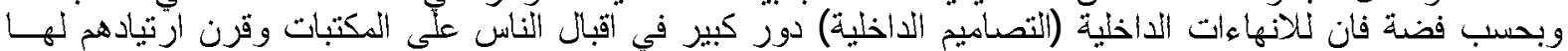

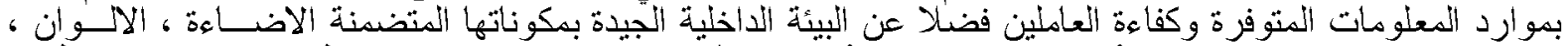

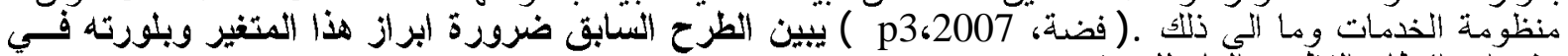
مفردات الاطار النظز مي الثعام للموضوع .

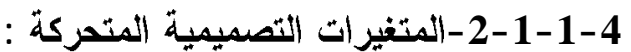

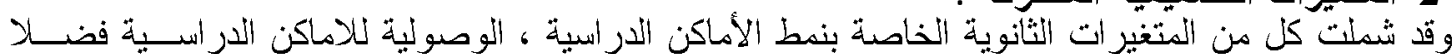

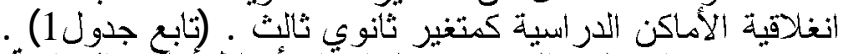

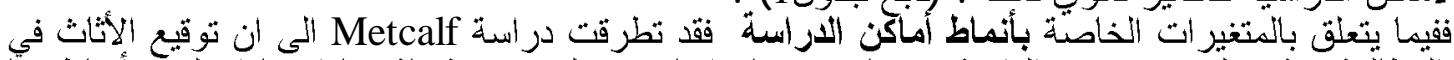

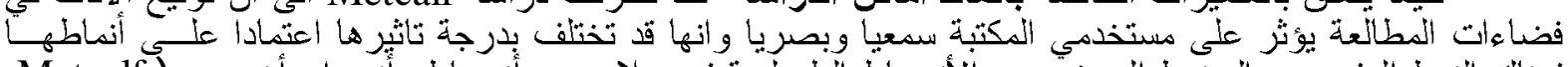

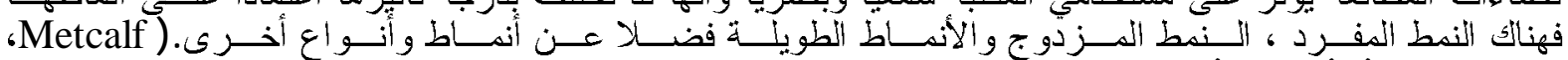
. (الثكل (1).314،1975

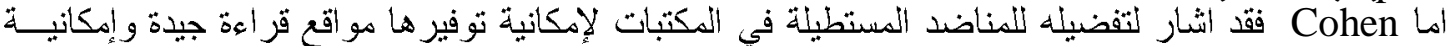

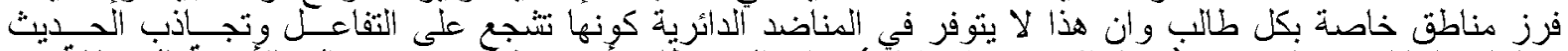

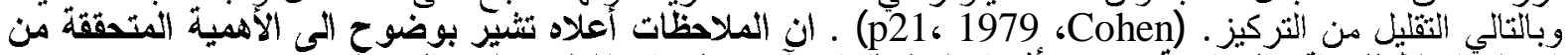

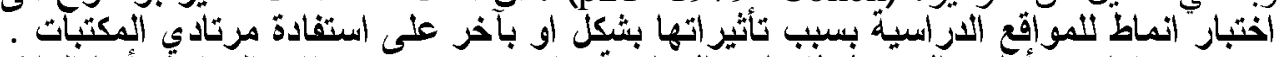

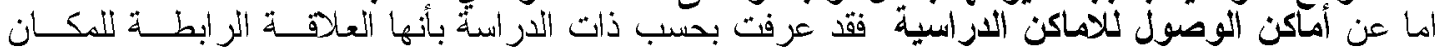

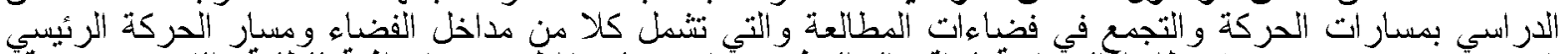

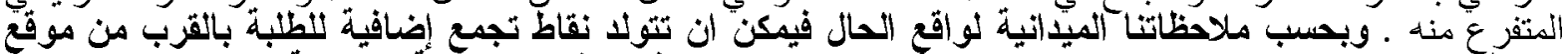

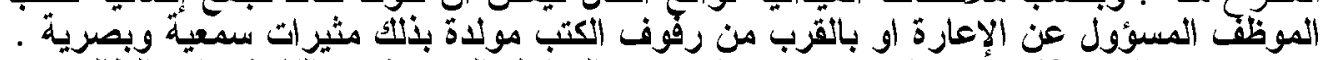

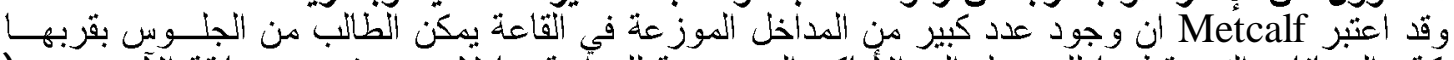

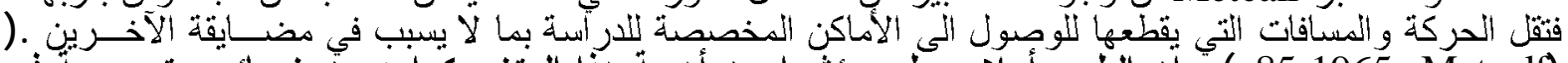
(p85،1965، Metcalf)

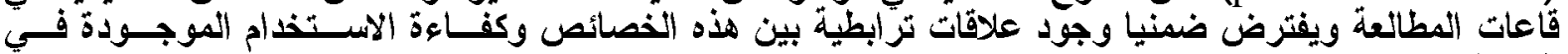

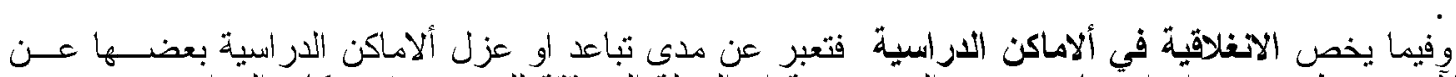
المكتبات . المطات

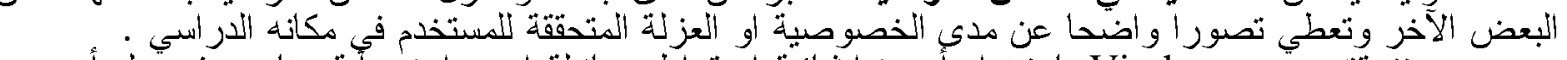

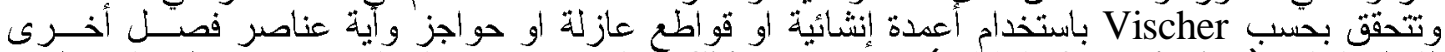

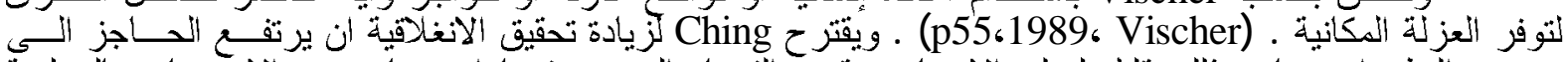

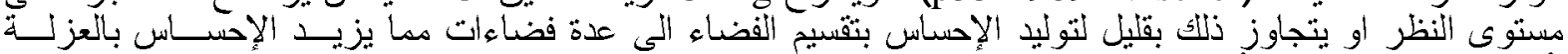
( (p14461979،Ching)

يتضح مما ورد انفا أهمية كون الانغلاقية واحدة من العوامل المؤثثرة على استفادة مرتادي المكتبات مـــ

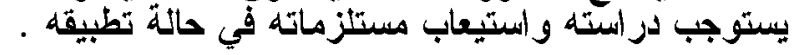




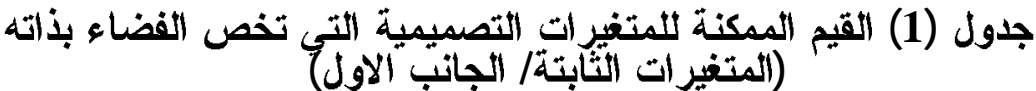

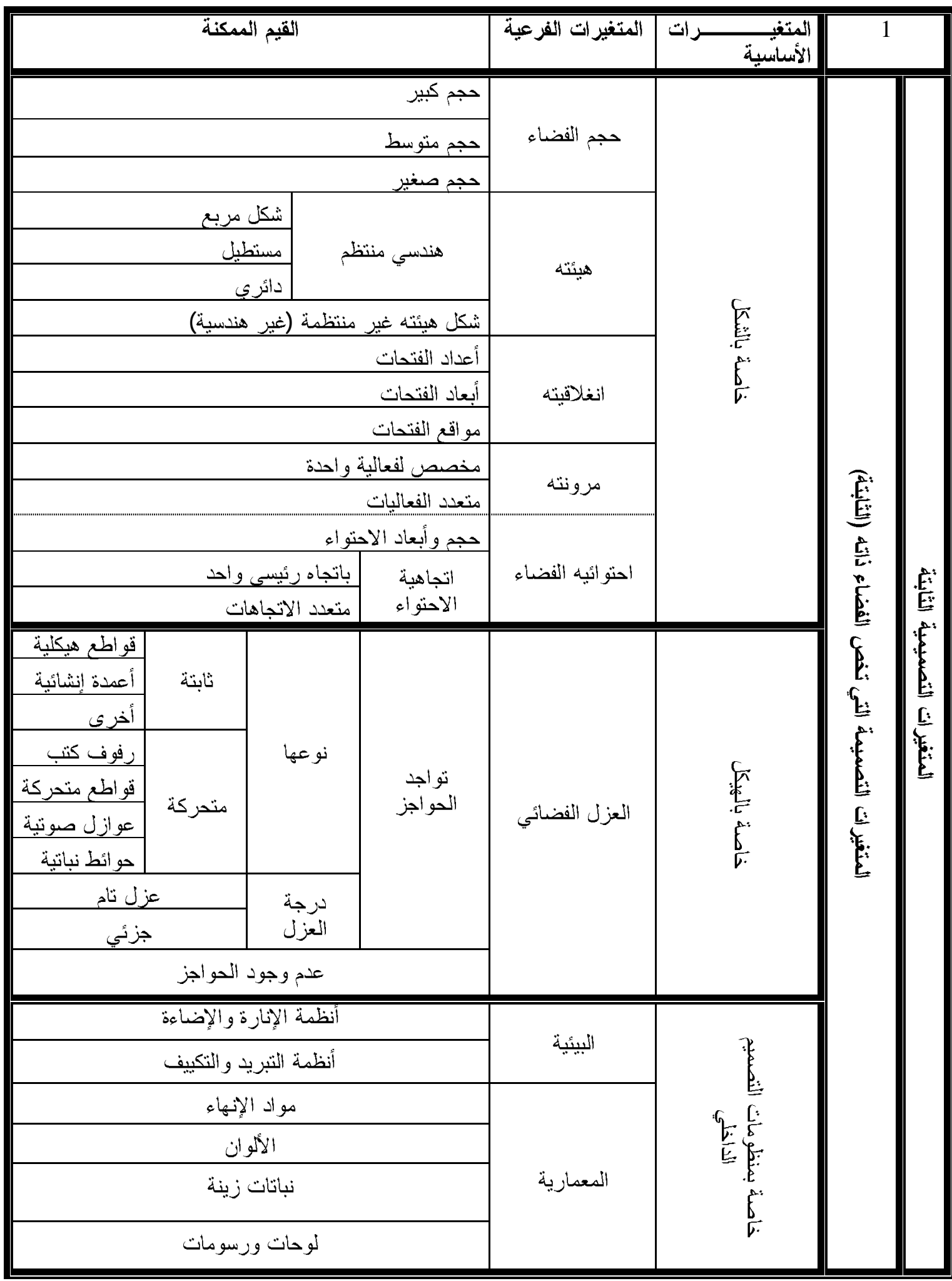


منونة: الخصائص التصميمية المؤثرة على كفاعة استخدام فضاءات المطالعة في المكتبات الجامعية

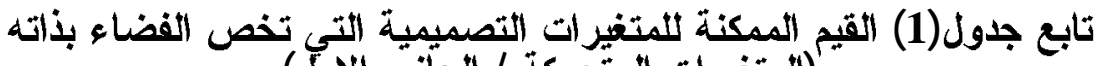

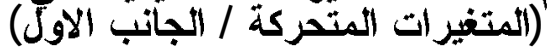

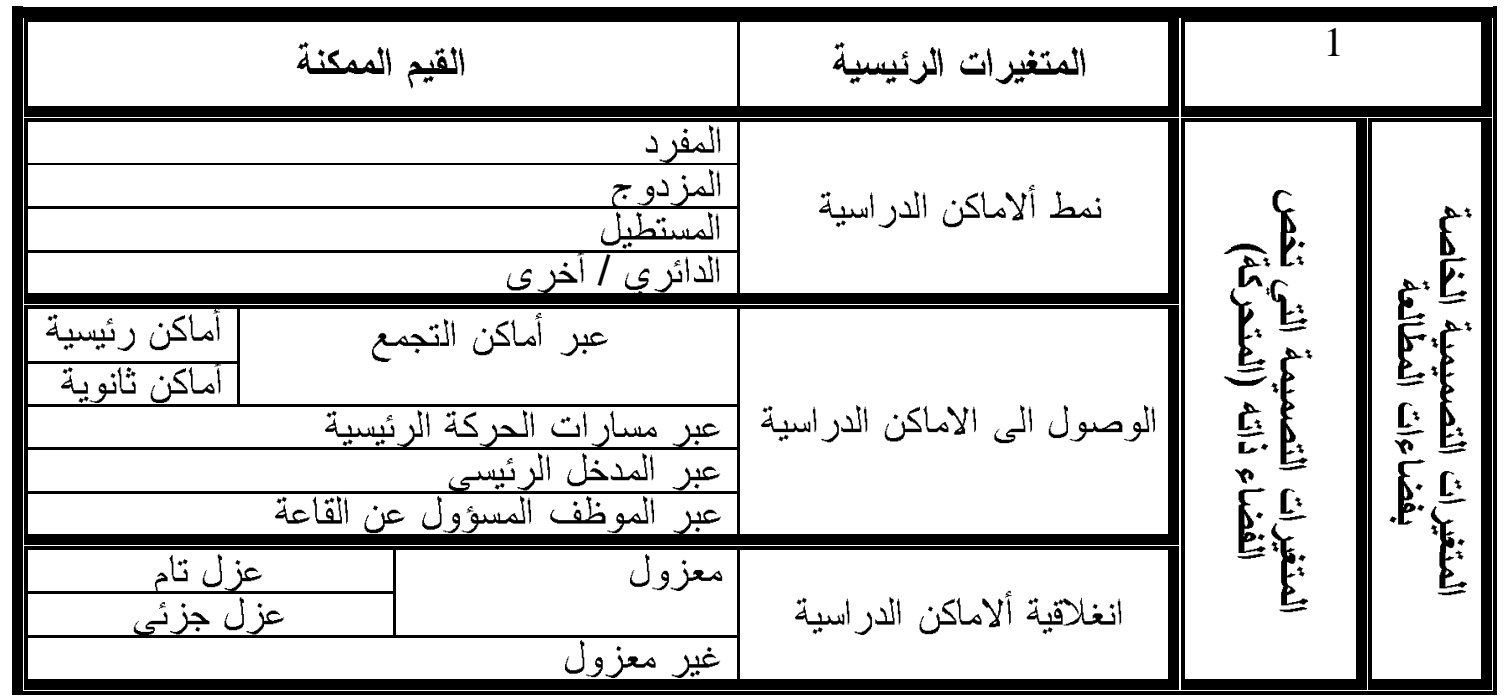

ملاحظة مهن

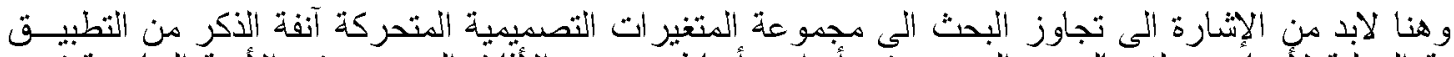

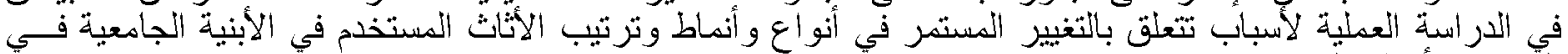

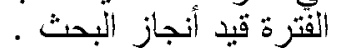

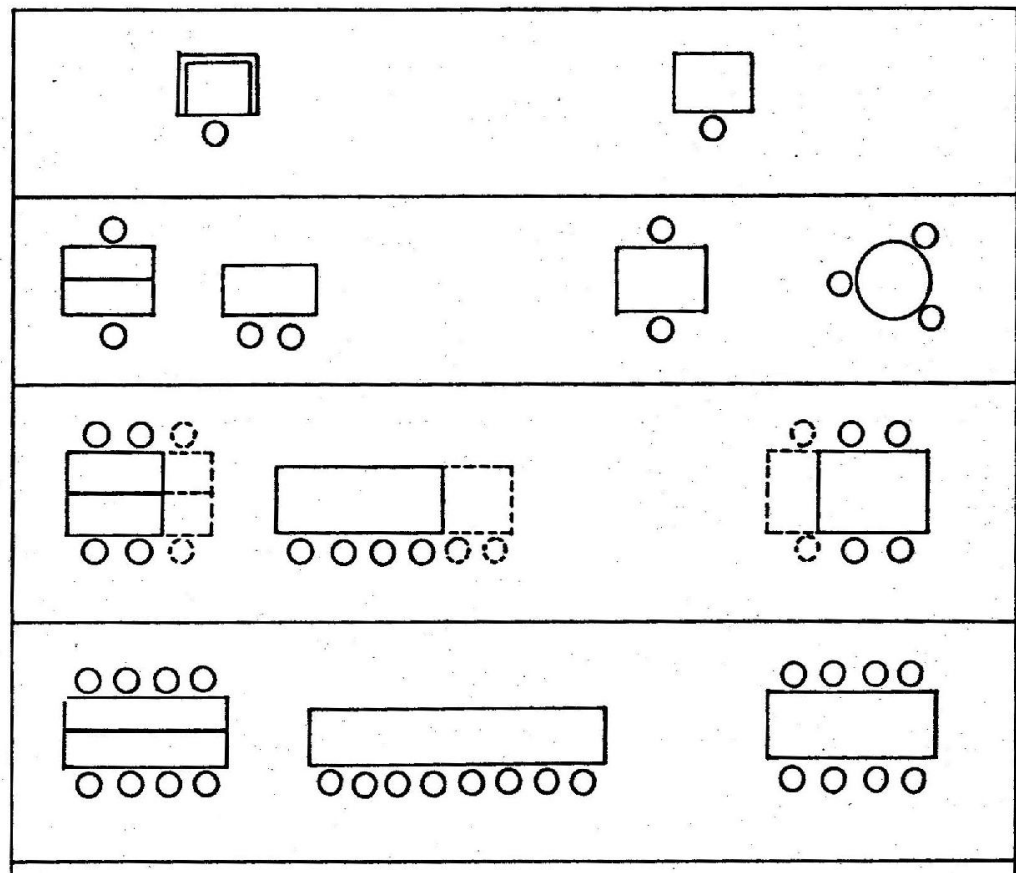

$$
\text { شكل (1) انماط المواقع الدراسية }
$$

4 - 4 - المتفيرات التصميمية التي تخص علاقة الفضاء مع الفضاعات الاخرى

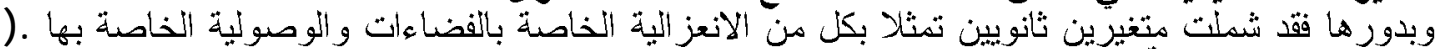

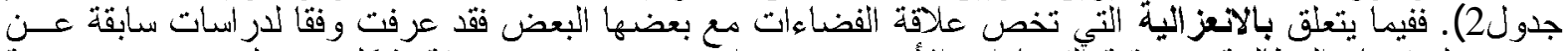

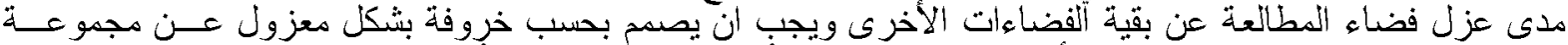

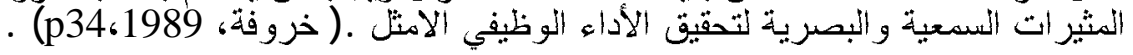



Al-Rafidain Engineering
Vol.19
No.1
February 2011

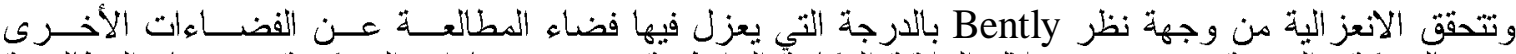

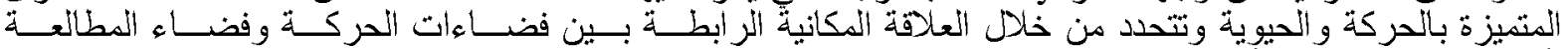
(p16، 1985،Pently)

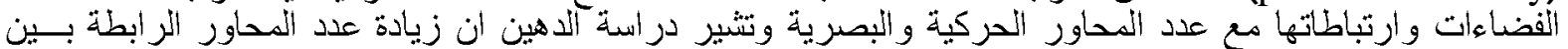

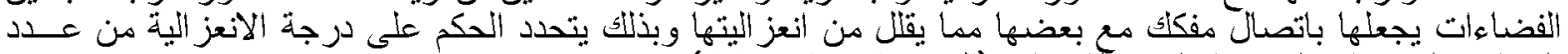

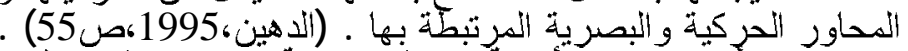

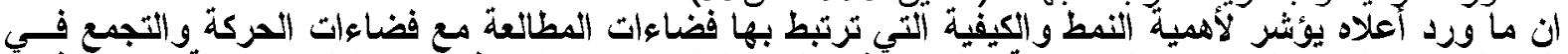

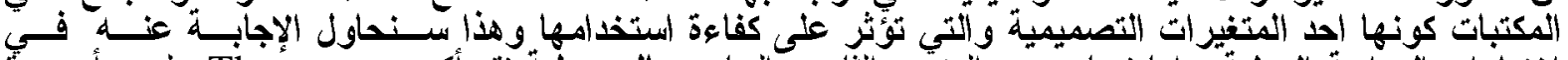

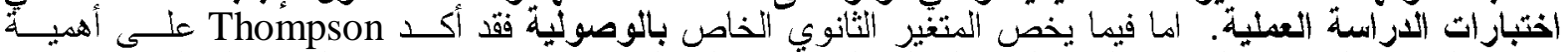

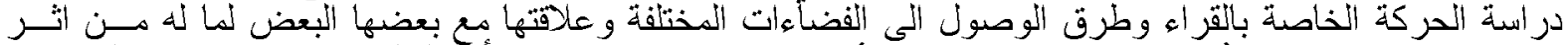

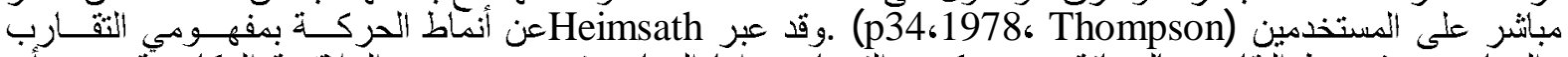

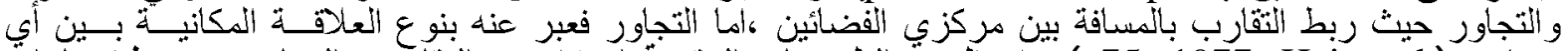

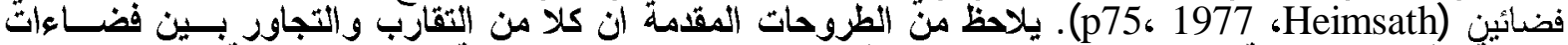

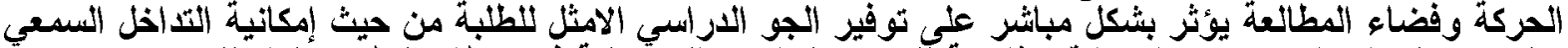

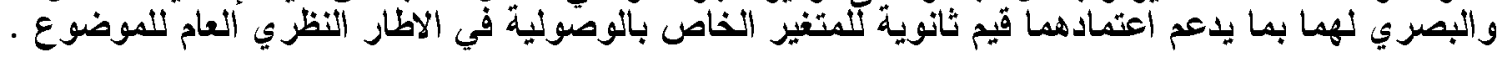

جدول (2) القيم الممكنة للمتغيرات التصميمية التي تخص علاقة الفضاء مع الفضاءات الاخرى الجانب الآول

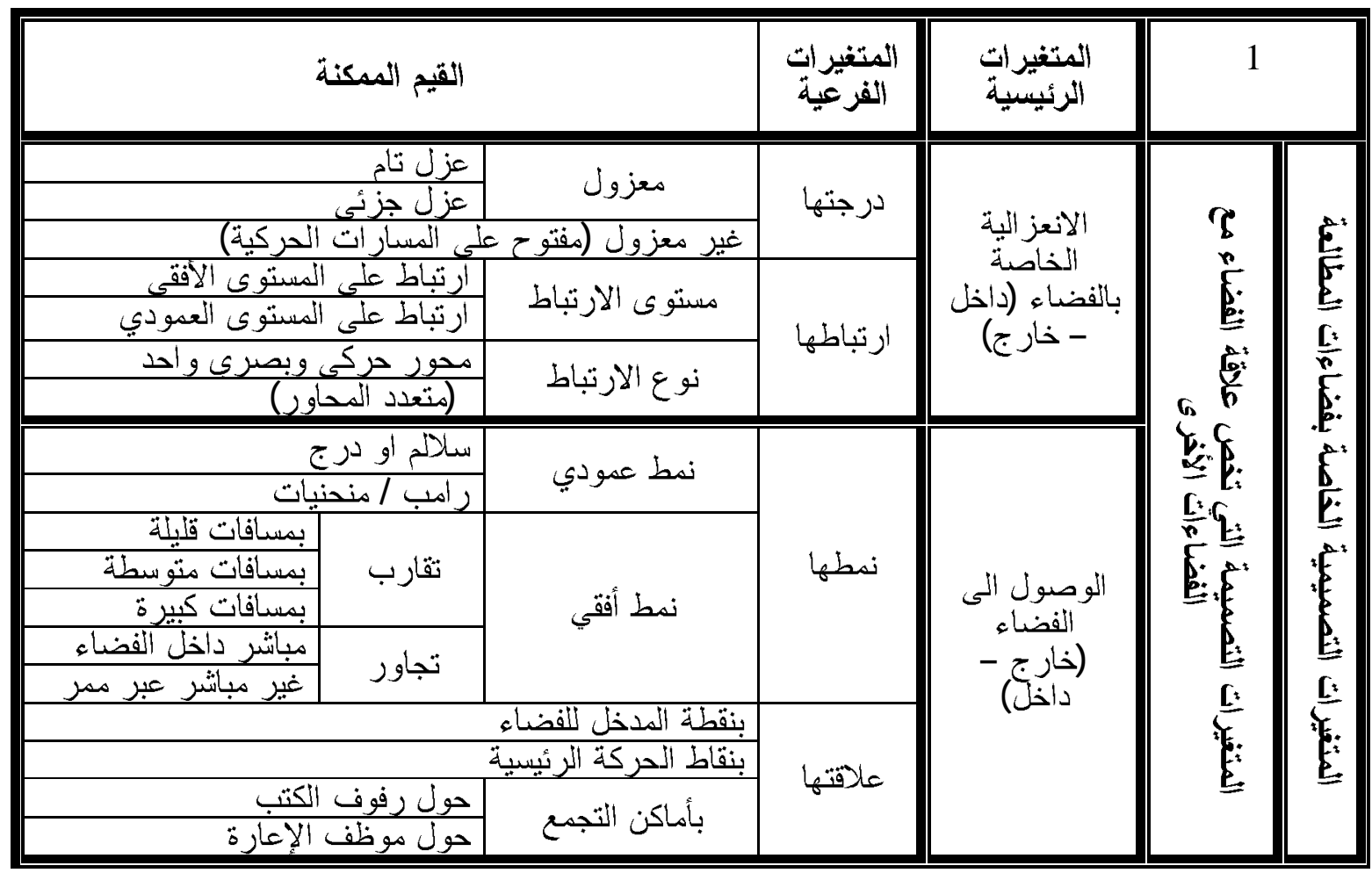

2-4 الجانب الثاني / كفاءة الاستخدام

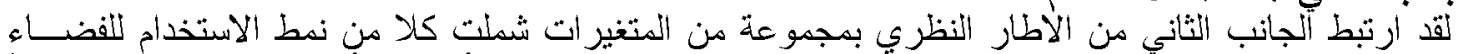

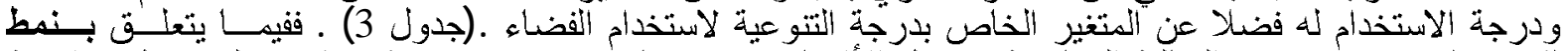

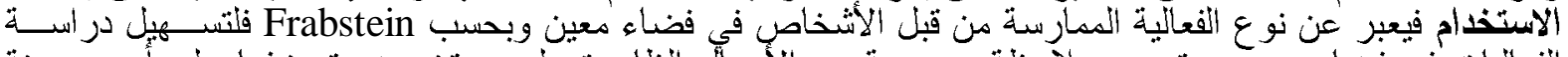

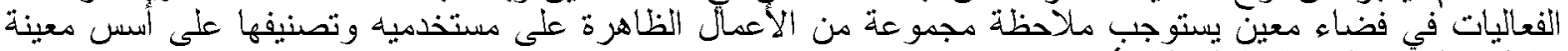
(p18- 25، 1974، Frabstein).

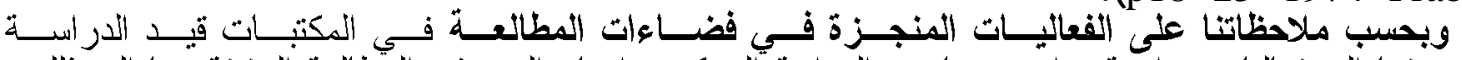

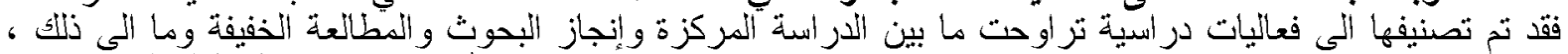

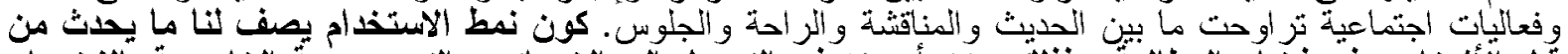

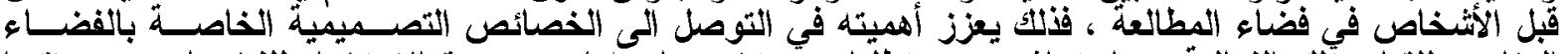

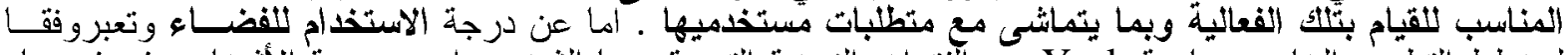

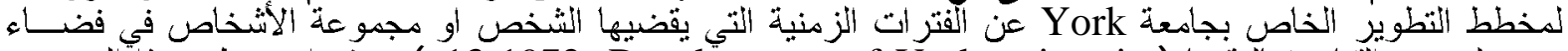

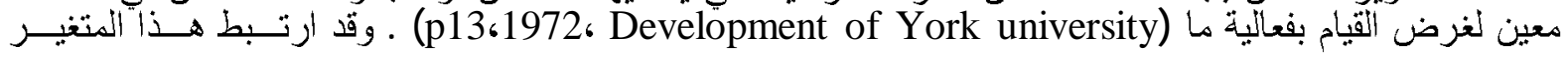




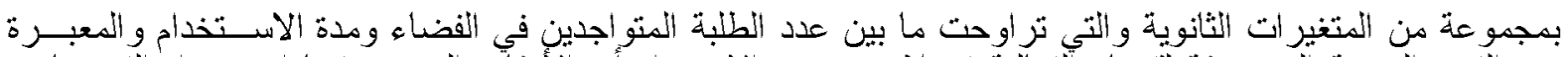

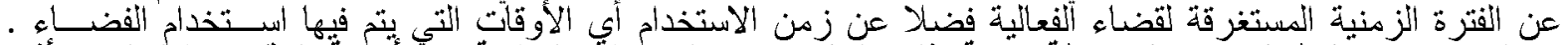

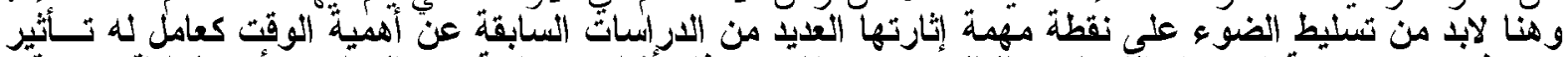

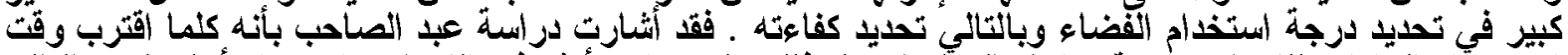

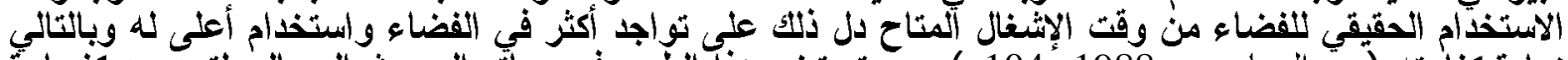

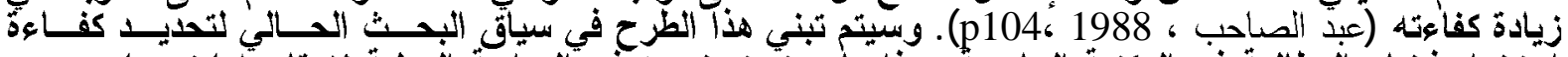

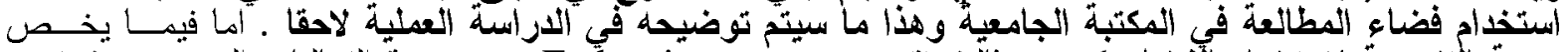

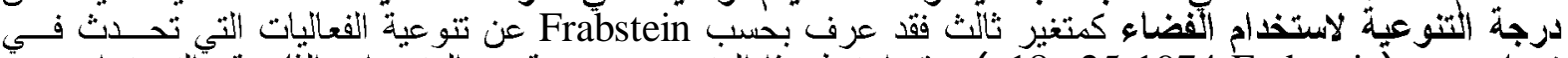

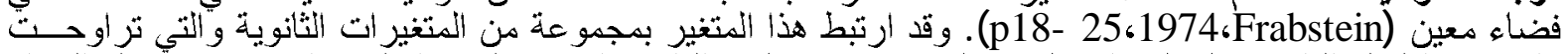

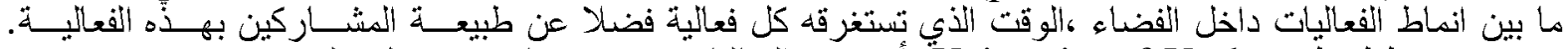

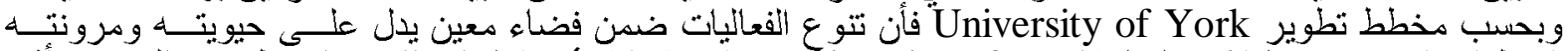

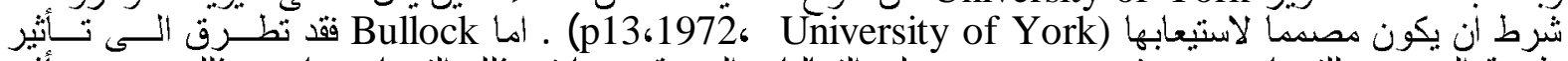

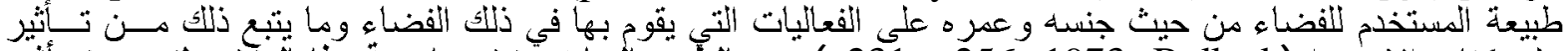

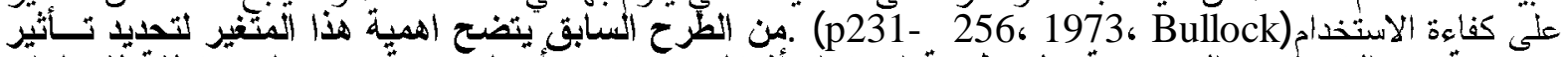

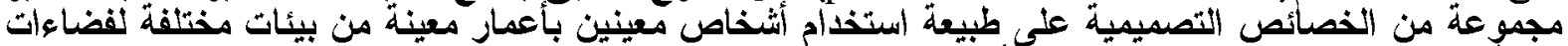

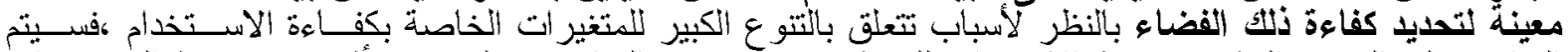

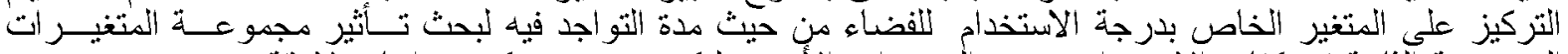

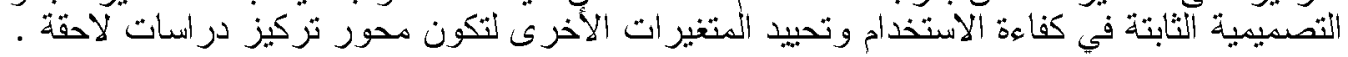

جدول (3) القيم الممكنة للجانب الثاني : كفاعة الاستخدام

\begin{tabular}{|c|c|c|c|}
\hline \multicolumn{2}{|c|}{ القيم المككنة } & المتغيرات الفرعية & المتغيرات الرئيسية \\
\hline & ير اسةّة مركزة & \multirow{3}{*}{ در اسة( بحث) } & \multirow{6}{*}{ ندط الاستخدام } \\
\hline & أنجاز بحوفت & & \\
\hline \multirow{3}{*}{\multicolumn{2}{|c|}{ 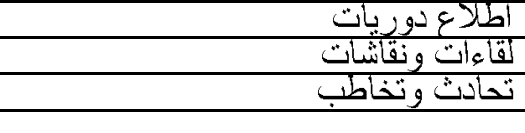 }} & & \\
\hline & & \multirow{2}{*}{ اجتماعي } & \\
\hline & & & \\
\hline & & تزفئكي & \\
\hline & أعداد كييرة & \multirow{2}{*}{ أُعداد الطلبة } & \multirow{9}{*}{ درجة الاستخدام للفضاء } \\
\hline & | اعداد متوسطة & & \\
\hline & اقل من 15 دقيقة & \multirow{5}{*}{ مدة الاستخدام } & \\
\hline & بين (15 - 30) בق & & \\
\hline & بين (60) - & & \\
\hline & بين (60 - 120) 20 & & \\
\hline & اكثز من ذلإن & & \\
\hline \multirow{2}{*}{\multicolumn{2}{|c|}{ 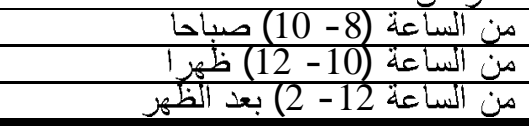 }} & \multirow[b]{2}{*}{ زمن الاستخدام } & \\
\hline & & & \\
\hline \multirow{2}{*}{\multicolumn{2}{|c|}{ فععالّية و اححة }} & \multirow[b]{2}{*}{ اعداد الفعاليات الممارسة } & \multirow{10}{*}{ درجة التتو عية للفضاء } \\
\hline & & & \\
\hline ير اسات عليا & متنصر ص سلر & \multirow{6}{*}{ طييعة المشاركين في } & \\
\hline طلبّة مز احل اولية & & & \\
\hline باحثين & & & \\
\hline |ساتذة & & & \\
\hline موظفين & \multirow[t]{2}{*}{ غبز متخصصبن } & & \\
\hline اخزى | ل اخ & & & \\
\hline \multicolumn{2}{|c|}{ فتزات منقزبة } & \multirow{2}{*}{ اللوقت المستغرق اللفعالية } & \\
\hline \multicolumn{2}{|c|}{ فتز ات متباعدة } & & \\
\hline
\end{tabular}

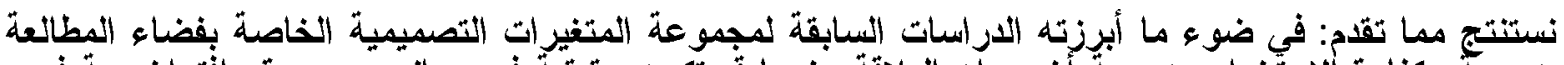

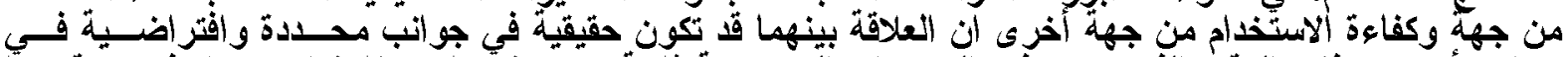

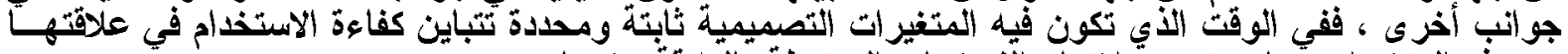

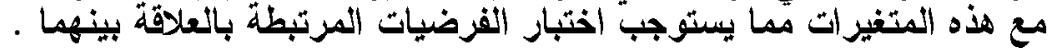




\section{5}

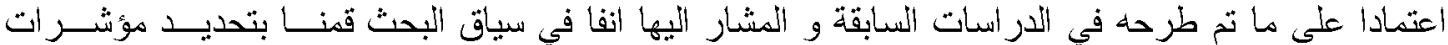

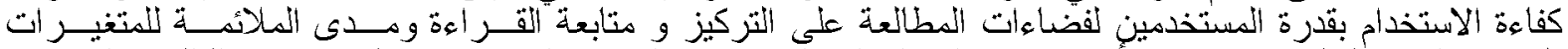

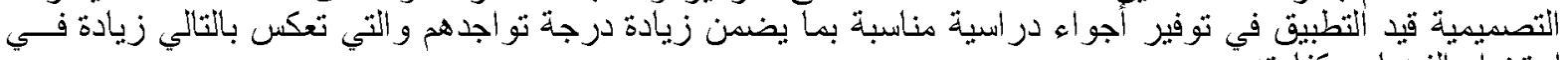

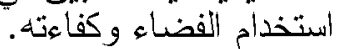

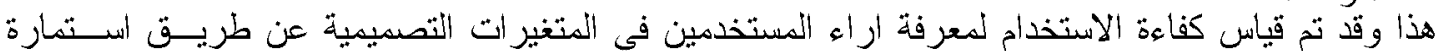

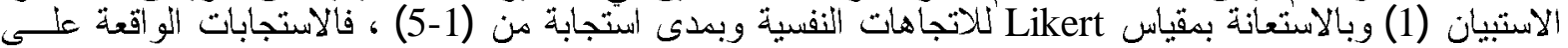

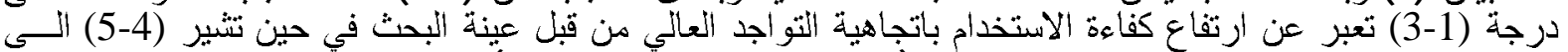

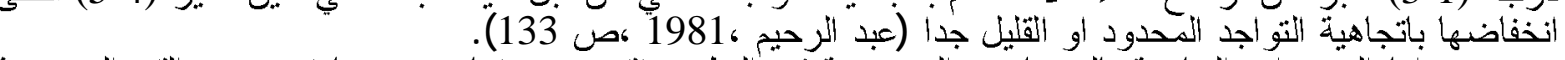
أما المتغير ات الخاصدة بالخصائص التصميمية فيد التطبيق فقد تم وصفها وترميز ها في ضوء القيم الموضحة

\section{6 - الار اسة العملية / التطبيق ومستلزماته}

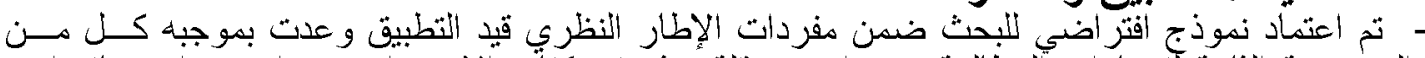

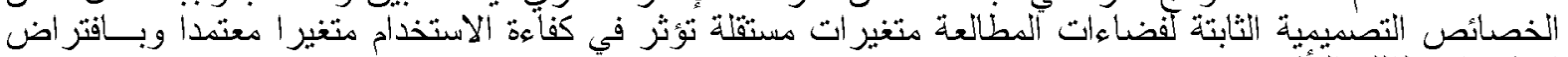

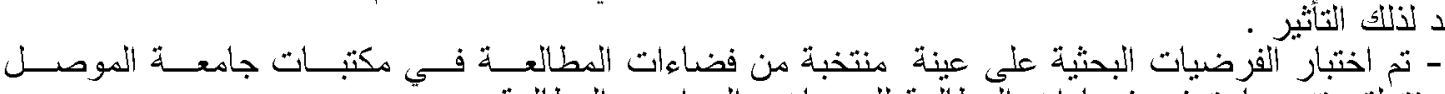

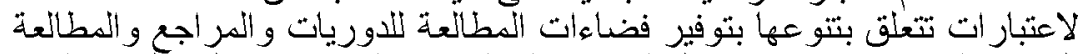

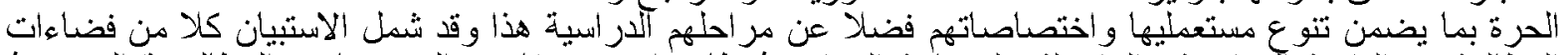

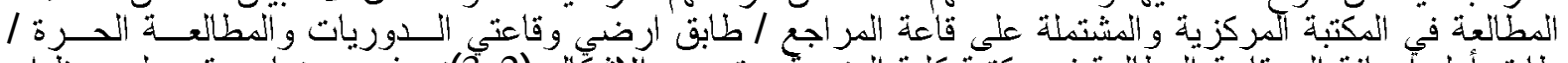

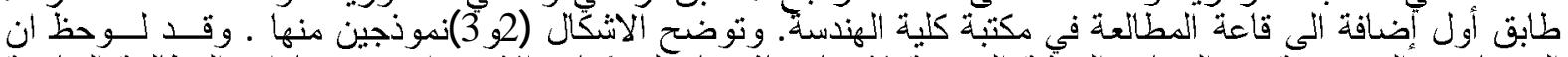

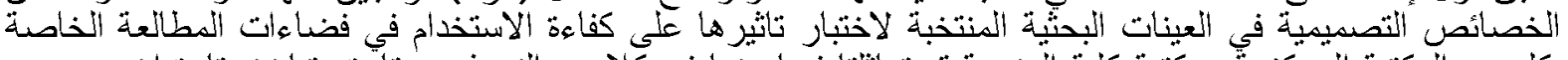

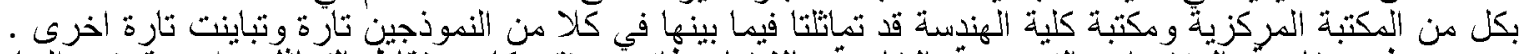

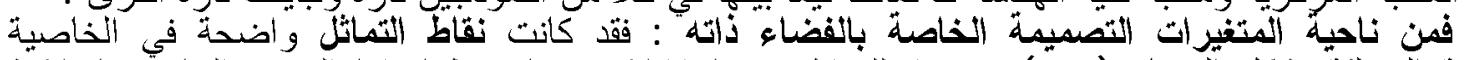

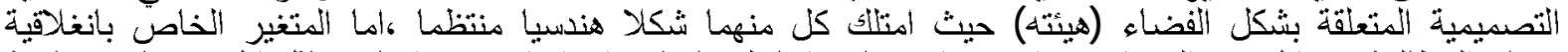

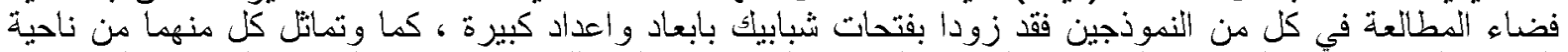

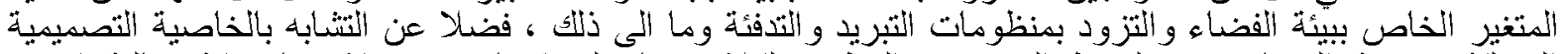

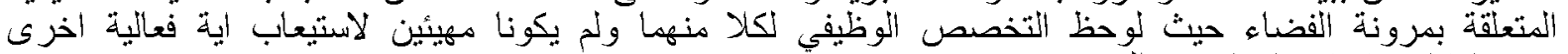

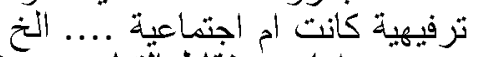

الما عن نقاط التباين بين فضاءي المطالعة في كل من النموذجين قيد النطبيق فقد بدت حاضرة في الخاصية

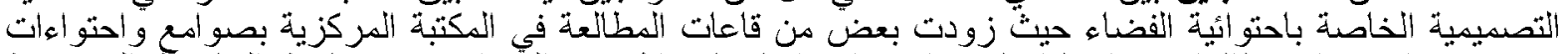

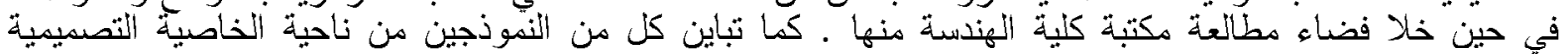

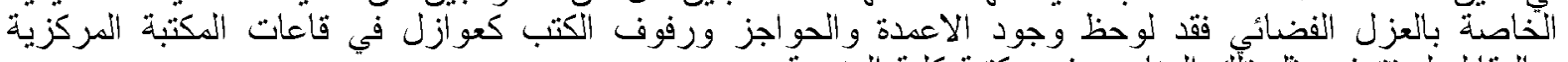

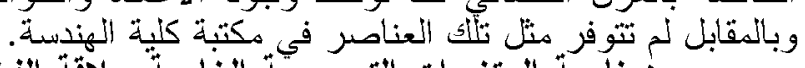

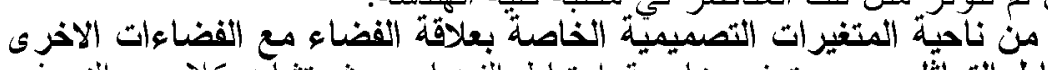

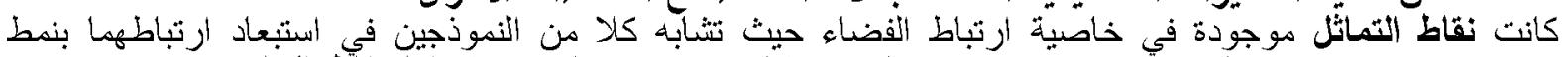

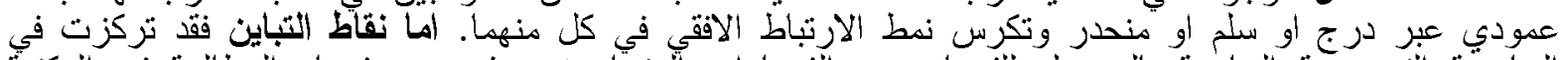

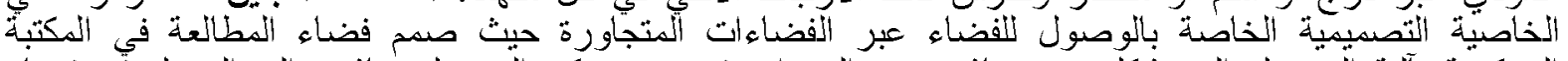

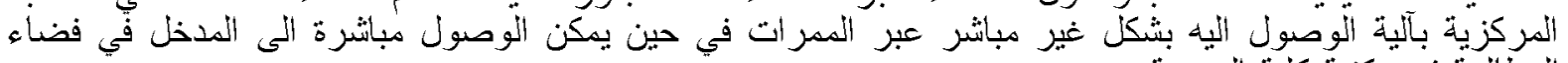

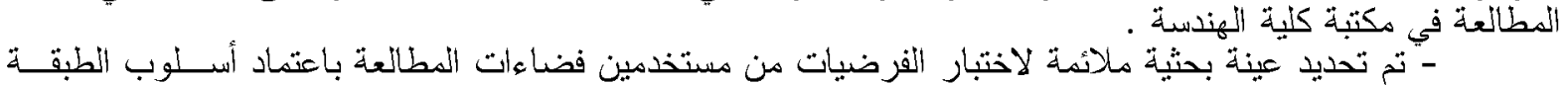

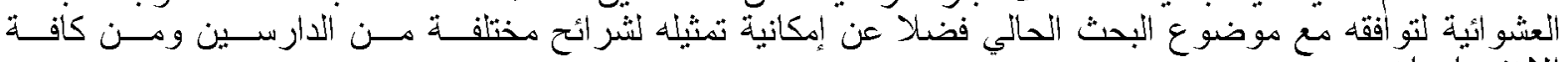

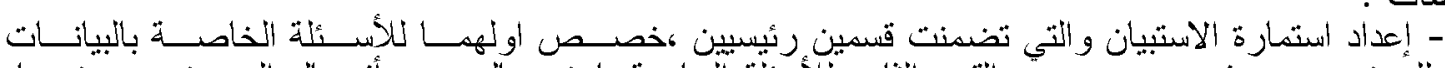

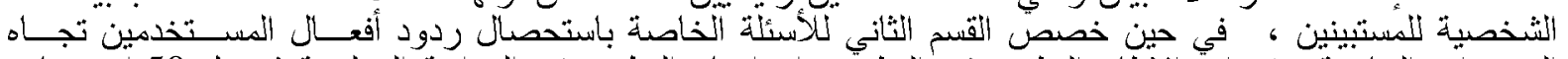

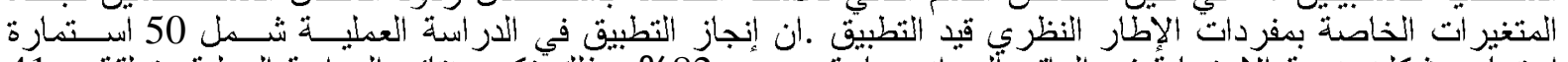

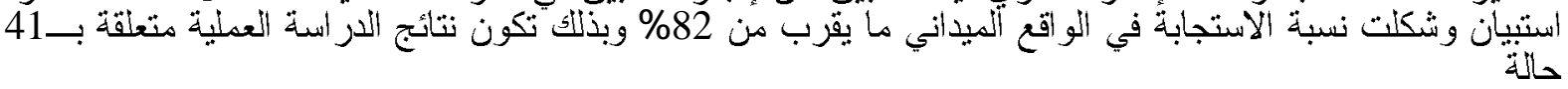

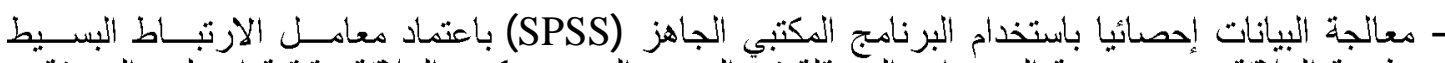

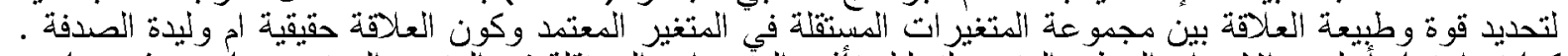

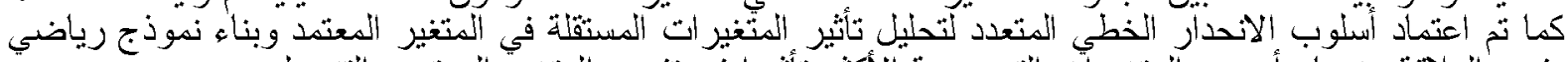

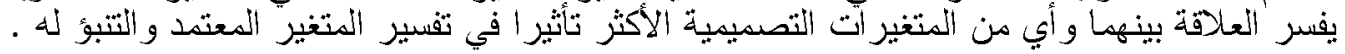


منونة: الخصائص التصميمية المؤثرة على كفاعة استخدام فضاءات المطالعة في المكتبات الجامعية

استمارة استبيان (1)

ادناه استمارة استبيان تتضمن مجموعة هن المعلوماتيات والاستقسار ات لمعرفة تاثير مجموعة من

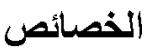

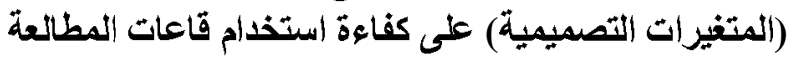

• رجاء| الشر تحت الببيل المناسب.

\begin{tabular}{|c|c|c|c|c|c|}
\hline \multicolumn{2}{|r|}{ | (لعمر: } & \multicolumn{2}{|r|}{ | الجنس : } & | المرحلة الاراسياّة: & |لمرحلة الآل \\
\hline 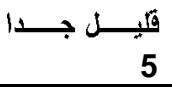 & ה & متوســـــــ & كبيـــ & كبيــر جـــ & 1 -اجد ان الحجم الكبير للقاعة يحفزني على البقاء والمطالعة بشكل \\
\hline ســ & غير مفيــ & مفيد اللى حـ 3 & 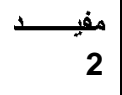 & هفيــد جـ & 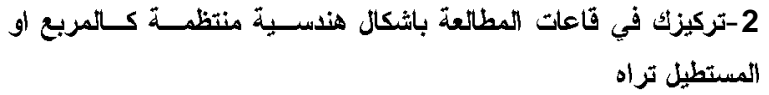 \\
\hline غير مفيد تماما & غير مفيــ & الى حد مـ & 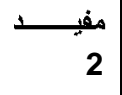 & مفيد 1 & 3 الخلوسك في قاعة مطالعة بفتحات شبابيك تجطنك بتواصل بصري مــع \\
\hline 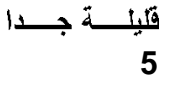 & 4 & متوســــــة & كبي & كبيرة جـد & 4 وتوجود الفتحات باحجام كبيرة في الجثران الخارجية بؤثر على تركيزك \\
\hline تعيز مناســـ & غير مناسب & الّى حد مـا & مناســـب & | & 5 لفعاليات ترفيعاب قاعة المطالعة لفعاليات اخرى اجتماعية مثل المناقتئسات أو \\
\hline 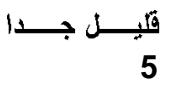 & $\sqrt{4}$ & متوســـــــ & 2 & عالتي جـا & 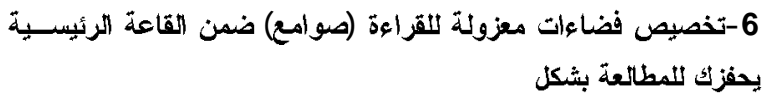 \\
\hline Hـ & 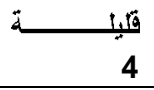 & متوســــــة & كيبـــــــــ & كبيرة جـــا & 7 وجود الجدران والحواجز او الاعددة يجعنك ثقبل على القرايودَ براحة \\
\hline ترتــاح نــنلك & 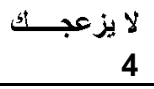 & 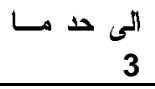 & 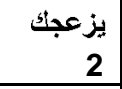 & | بزعجك جدا & 8 -جلوسك بالقرب من رفوف الكتب : \\
\hline 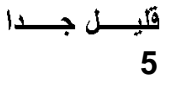 & 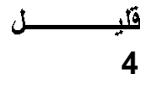 & متوســـــــ & كبيــــــ & كبيــر جـــ1 & 9 - يزويد القاعة بانظمة مركزية للتبريد والتدفئة بما بخلق اجواعا مريحة \\
\hline قصـيزة جـا & 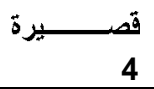 & متوســـــة & 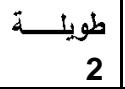 & طويلة جـــ1 & 10 -ارتاح لوجودي في قاعة بخطة لونية معينة وامكث لفترات \\
\hline قصـيزية جـا1 & 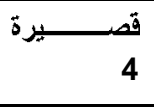 & متّوســـــة & طوي! & طويلة جــ1 & 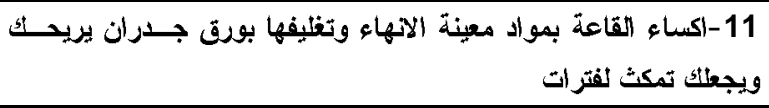 \\
\hline ســــ & غير مناسب & الثى حد مـا & 2 & 1 & 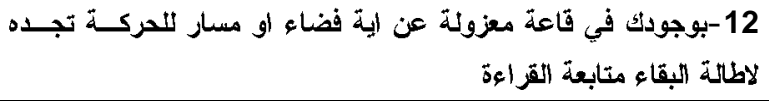 \\
\hline - & غير مفيــ & الثى حد مـ & مفيــــــــ & 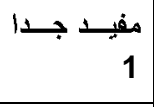 & 13 كلو توفرت وسيثلة ربط بلرج مح قاعة اخرى للفعائية اخرى هل ترى \\
\hline قليـل جـ & $\underbrace{3}_{4}$ & متوســــــ & عــــالي & عائي جـ1 & 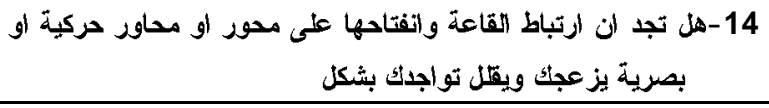 \\
\hline 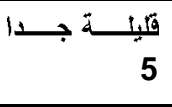 & $\frac{1,16}{4}$ & متّوســـــة & كيبــــرة & كبيرة جــ1 & 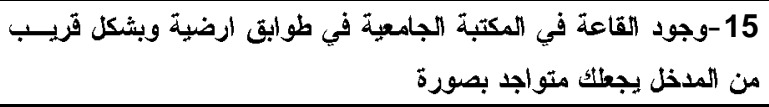 \\
\hline 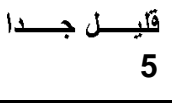 & $\underbrace{10}_{4}$ & متوبــــــ & 2 & عالتي جـ & 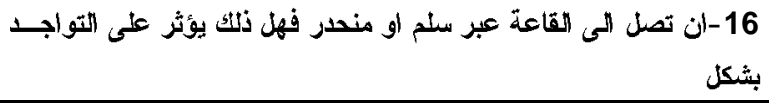 \\
\hline ســـ & غير مناسب & \begin{tabular}{rl|l}
3 \\
3
\end{tabular} & مناســـب & | & 17 متواجد اماكن المطالعة في القاعة قرب مدظلها تراه \\
\hline 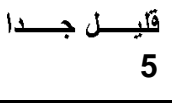 & 16 & متوبـــــــ & 2 & عالْي جــ1 & 18 -تجن ان حركة الطلاب للوصول الى الرفوف بشغلتك عن متابعة القرائوة \\
\hline 11 بـ & $\frac{116}{4}$ & متّوســـــة & 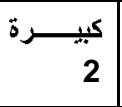 & كبيرة جـان & 19 التجمع الطلاب حول موظف الاعارة بعيقك عن المتابعة ولا تقبل على \\
\hline
\end{tabular}


$\begin{array}{llll}\text { Al-Rafidain Engineering } & \text { Vol.19 } & \text { No.1 } & \text { February } 2011\end{array}$

جدول (4) رموز وأرقام متغيرات الار اسة العملية قيا التطبيق

\begin{tabular}{|c|c|c|c|c|c|c|}
\hline زقت ورمز المتغير & \multicolumn{4}{|c|}{ الثرجاث الخاصة: بالقيج المدكنة للثتنيرات } & \multirow{2}{*}{ متغير ات الثراسة العمطية } & 4 \\
\hline \multicolumn{5}{|c|}{ اليتبرات التي تخص الفضاء بأتها } & & أولا \\
\hline $\mathbf{V}_{1}$ & حبم صفير & 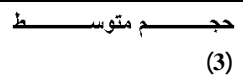 & 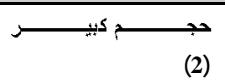 & 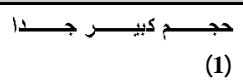 & حجم الفضاء & \\
\hline $\mathbf{V}_{2}$ & غير هندس & (3) & (2) & 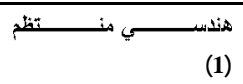 & يئة الفضاء (تكعله) & \\
\hline V3 & 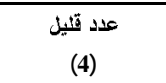 & 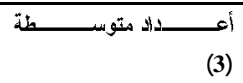 & 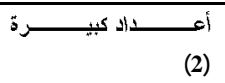 & 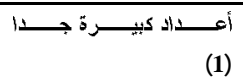 & انغلآتية الفضاء من حبث عداد & \\
\hline $\mathbf{V}_{4}$ & أبحساد صــيرة & 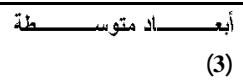 & 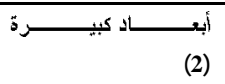 & 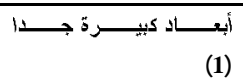 & انتلاثية الفضاء من حث عداد & \\
\hline $\mathbf{V}_{5}$ & أكثر من ألتك & 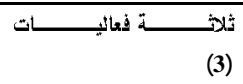 & (2) & أزعائيسة (1) & مرونة الفضاء & \\
\hline $\mathrm{V}_{6}$ & 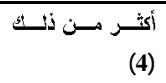 & (3) & |باتجــا هين رئيســـين & 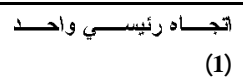 & احتوائية الفضاء & \\
\hline $\mathbf{V}_{7}$ & لا يوجل حواجز & (3) & 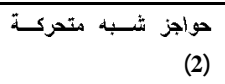 & (1) & العزل الفضائي من حيث نوع الحواجز & \\
\hline $\mathbf{V}_{8}$ & غيــر معــزود & 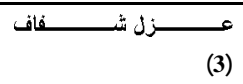 & عزل تشسبه تسام جزئسي & 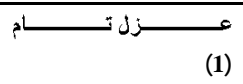 & العزل الكضائي من حيث يرجة العزل & \\
\hline $\mathbf{V}_{9}$ & 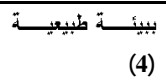 & (3) & 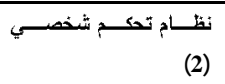 & نظسام مركزي خسارجي & بيئة الفضاء من حيثة ألظطة التبريد & \\
\hline$V_{10}$ & غير ملون & (3) متعد الألوان بذون خطــة & أكثر سـن خطـة لونيــة & خطـــة لمونيــة هو جـــة & معمارية الفضاء من حيث الثطة & \\
\hline$V_{11}$ & غير (4زود & 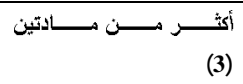 & (2) & 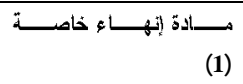 & معمارية إفضاء سن حيث مواد إنهاود & \\
\hline$V_{12}$ & 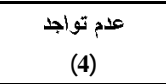 & تو (3) & تون & تواجل & معمارية الفضاء من حيث الجداريات & \\
\hline & & & & فضاءات الأخزى & 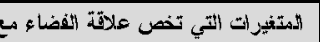 & تُانيا \\
\hline $\mathbf{V}_{13}$ & غير مغزول & عزن جزئي أكثر من مسار & 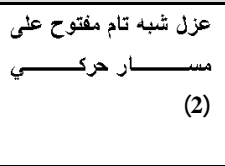 & عزلمركة تساج عـن مسـارات & 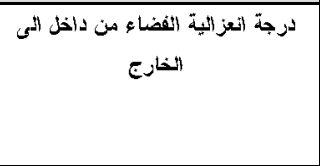 & \\
\hline$V_{14}$ & غير هرنتبط & (3) & 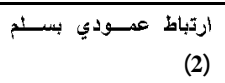 & 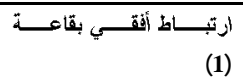 & هنيّو ث ارثباط الفضاء & \\
\hline$V_{15}$ & غير مرتبط & 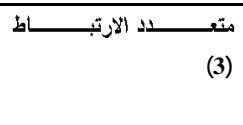 & 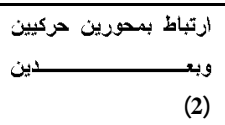 & 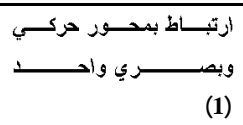 & نوع ارتباط الفضاء & \\
\hline $\mathbf{V}_{16}$ & باكثلز هـن ندـأ & 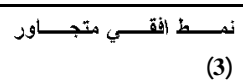 & 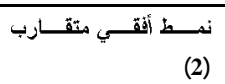 & 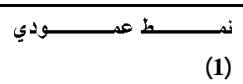 & التوصولية لافضاء من الخارج الى مئل & \\
\hline $\mathbf{V}_{17}$ & باكثر من طريقـتـة & 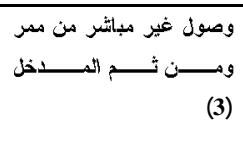 & وصول شببه مباتشر عبـر & وصول مباشز الثى اليــذل & التوصوبية للفضاء عبر الفضاءات & \\
\hline $\mathbf{V}_{18}$ & المروز بأكثر من (4) & 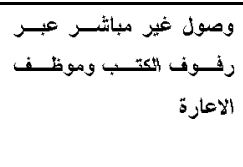 & 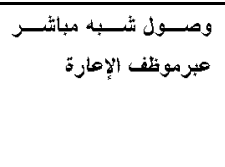 & 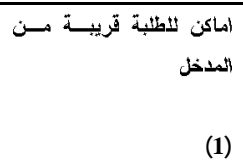 & وصوية الفضاء بائعلاثة بع نقاط & \\
\hline \multicolumn{2}{|c|}{ ئلة في التّو اجل و البقاءع } & (5). (4) & \multicolumn{3}{|c|}{ 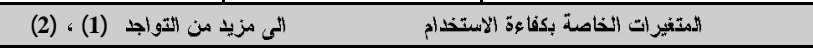 } & 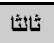 \\
\hline
\end{tabular}




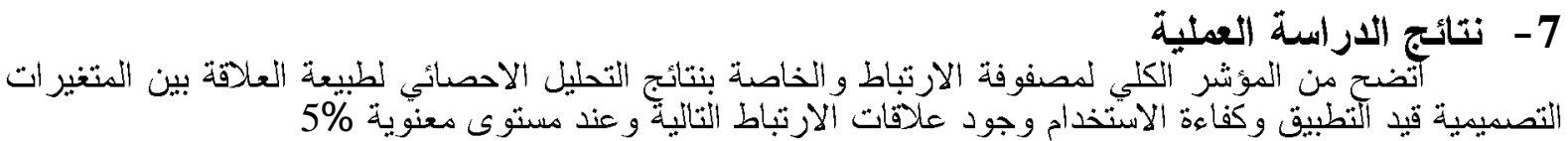
وجود علاقة ارتباط قوية موجبة وبمستوى معنوية عالي جدا للمتغير الخاص بالوصول للفضــاء مــن الفضــاءات

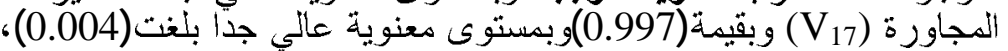

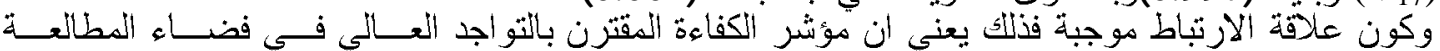

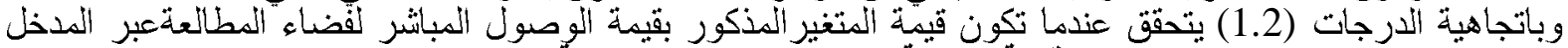

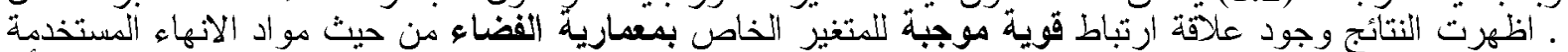

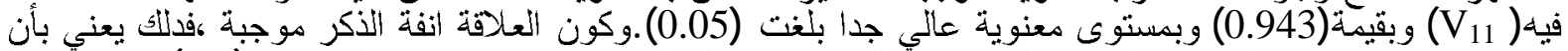

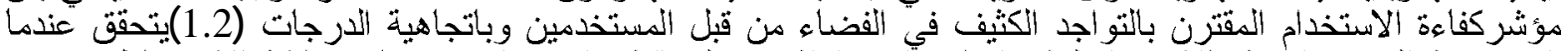

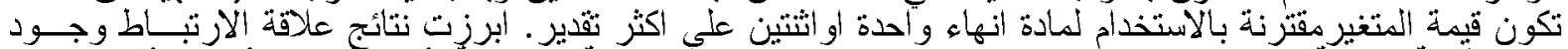

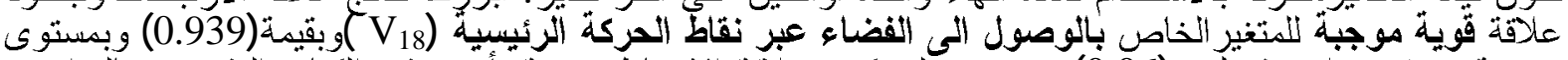

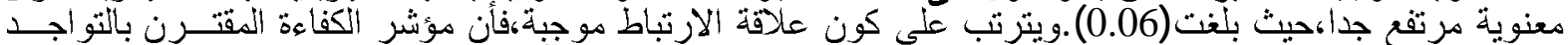

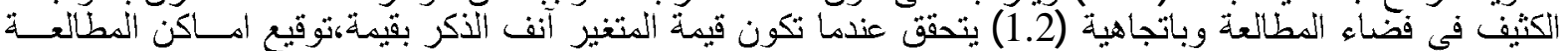

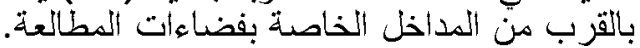

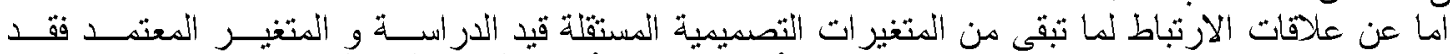

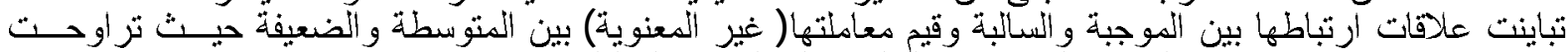

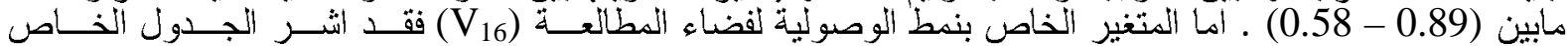

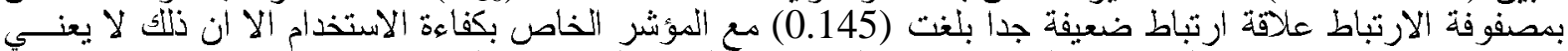

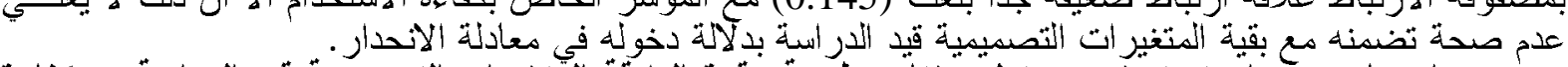

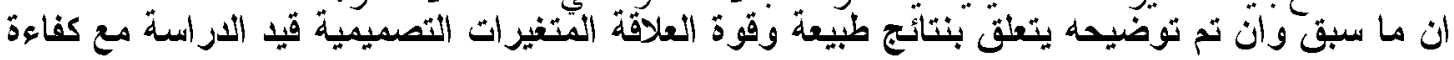

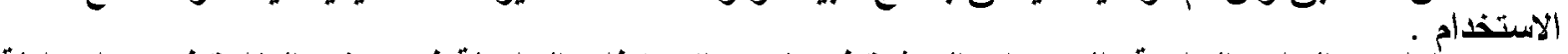
أما عن النتائج الخاصة بالمتغيرات المؤثرة في تفسير الاختلافات الحاصلة في مؤشر الكفاءة فتبرزها معادلة الاتحدار المتعدد

$\mathrm{Y}=-4.27-0.148 \mathrm{~V}_{1}+0.197 \mathrm{~V}_{2}+0.397 \mathrm{~V}_{3}+0.278 \mathrm{~V}_{4}+1.39 \mathrm{~V}_{5}-0.606 \mathrm{~V}_{6}-0.124 \mathrm{~V}_{7}+$ $0.030 \mathrm{~V}_{8}+0.918 \mathrm{~V}_{9}-0.348 \mathrm{~V}_{10}-0.357 \mathrm{~V}_{11}-0.04 \mathrm{~V}_{12}+0.525 \mathrm{~V}_{13}+0.075 \mathrm{~V}_{14}--.251 \mathrm{~V}_{15}+$ $0.357 \mathrm{~V}_{16}-0.058 \mathrm{~V}_{17}+0.141 \mathrm{~V}_{18}$

حيث يلاحظ تباين مجمو عة المتغير ات في نسب تاثير ها في كفاءة الاستخدام وان اعلى نسب تاثثير كانست للمتغيـرات الآتية:

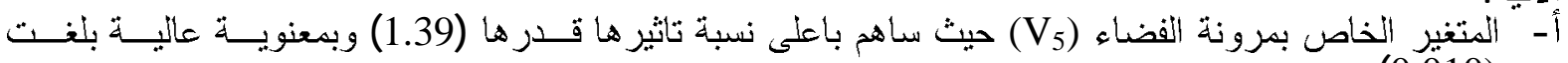
. (0.010)

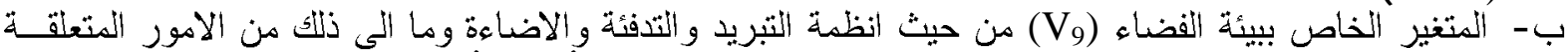

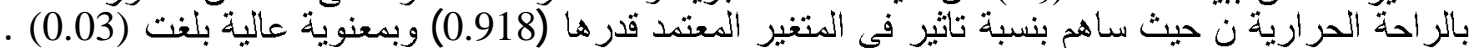

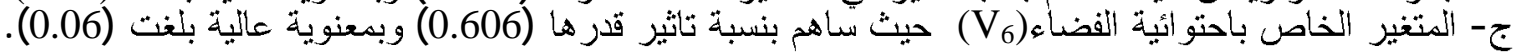

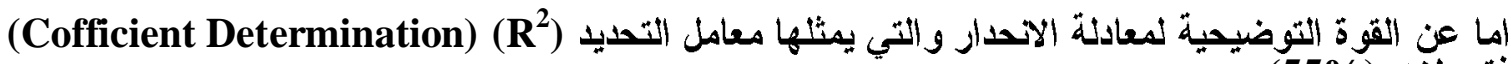

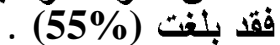

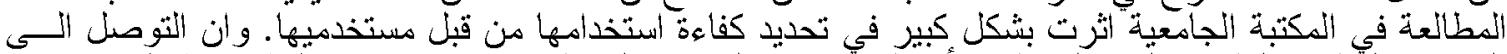

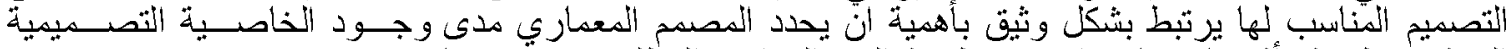

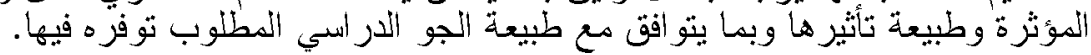

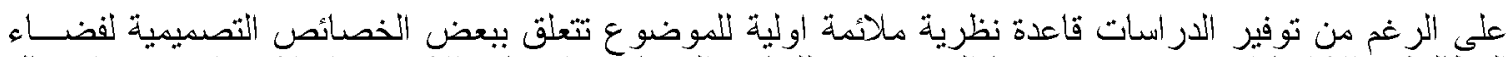

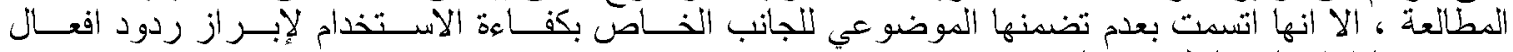

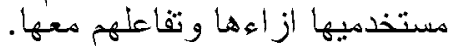

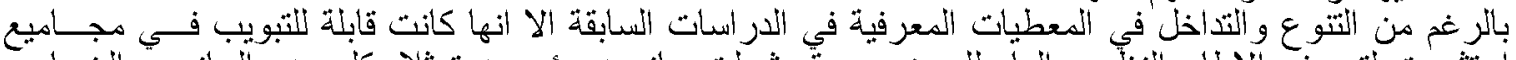

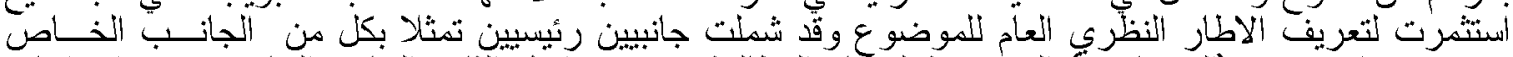

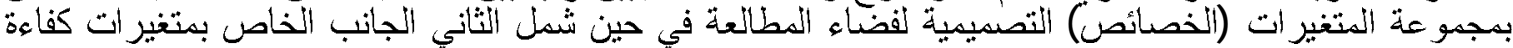

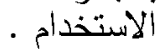


$\begin{array}{llll}\text { Al-Rafidain Engineering } & \text { Vol.19 } & \text { No.1 } & \text { February } 2011\end{array}$

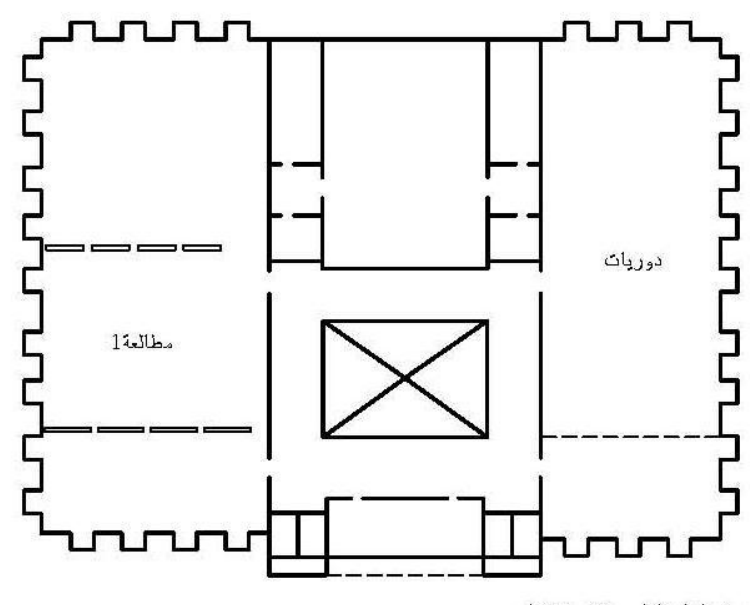

مخطط الطــابق الاول

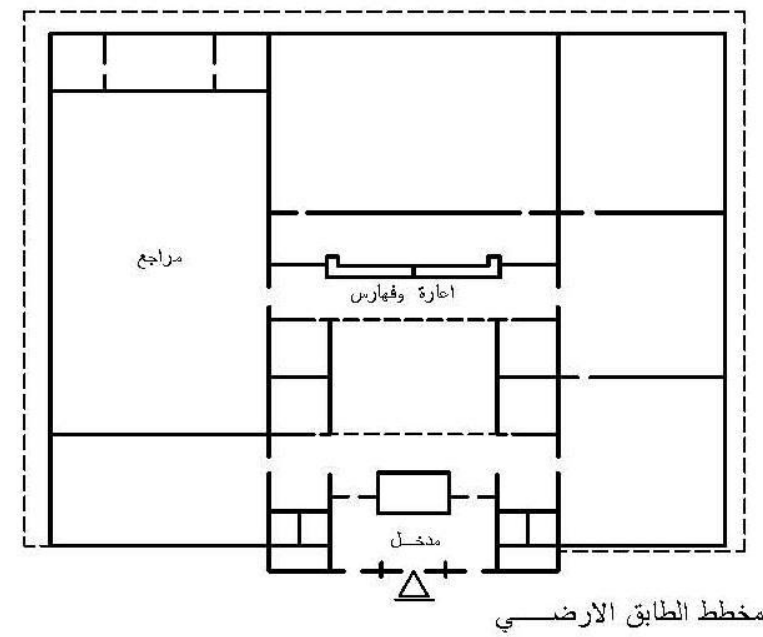

شكل (2) مخططات المكتبة المركزية/ جامعة الموصل

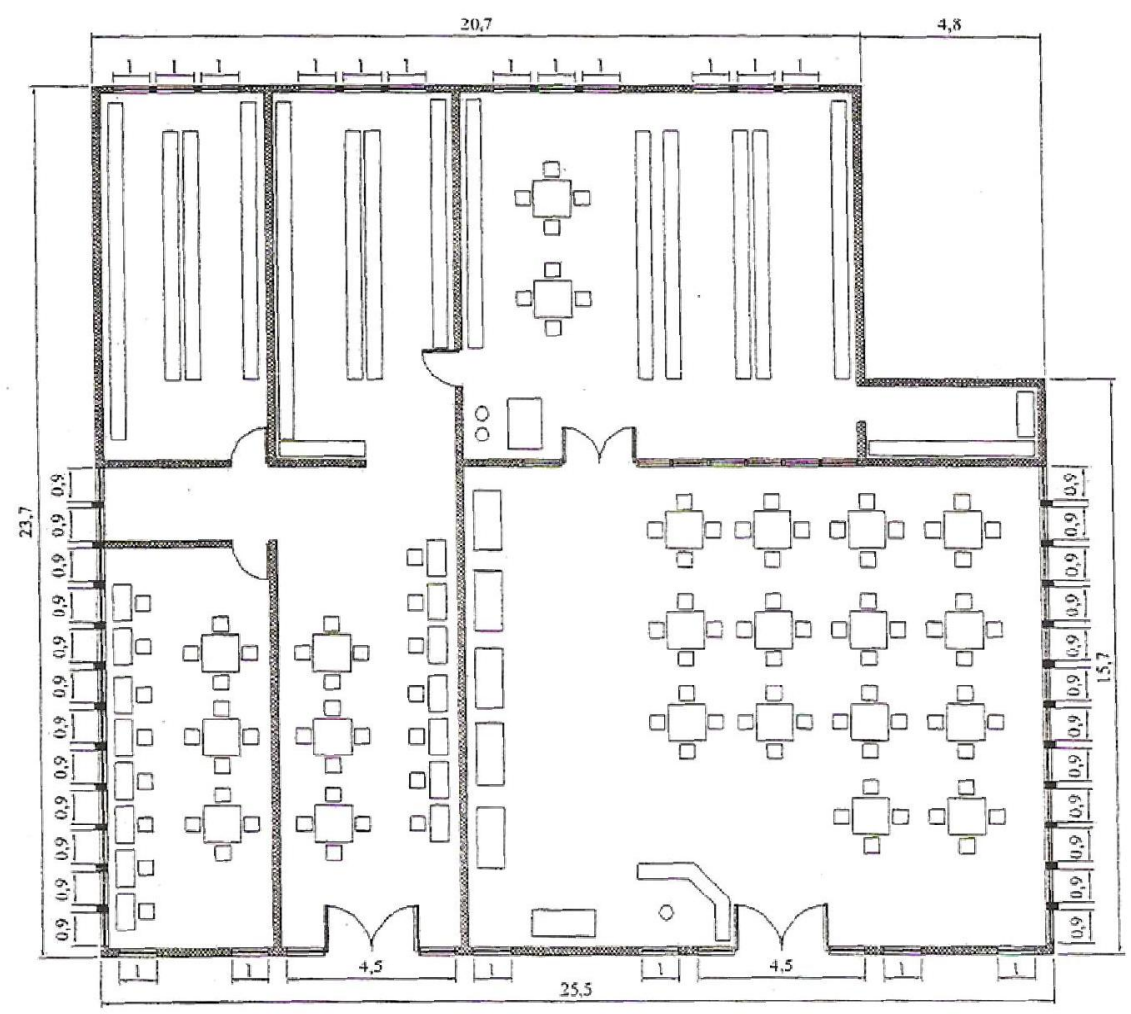

شكل(3)مخطظ مكتبة كلية الهندسة/جامعة الموصل

8

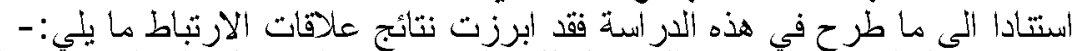

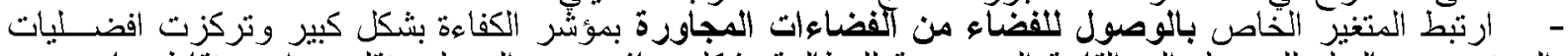

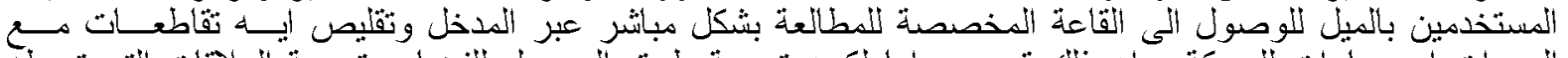

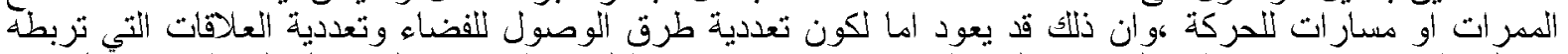

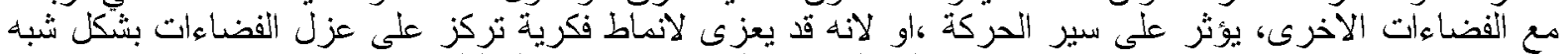

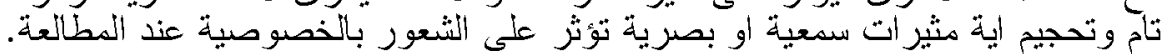




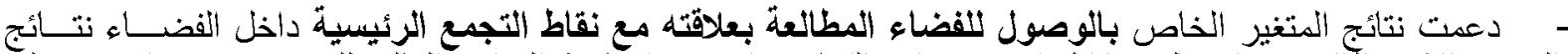

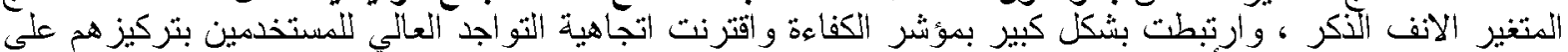

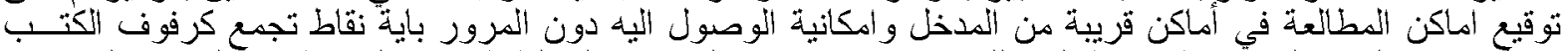

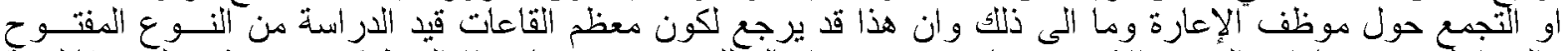

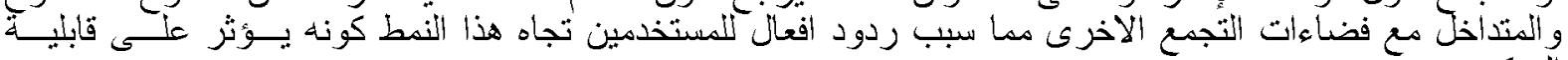
التركيز

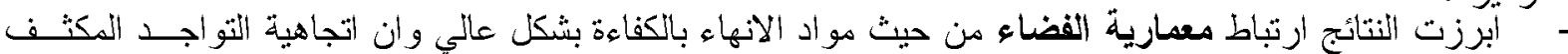

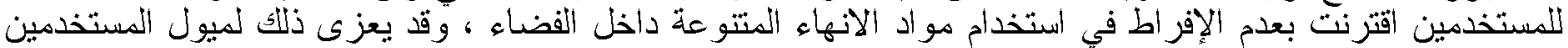

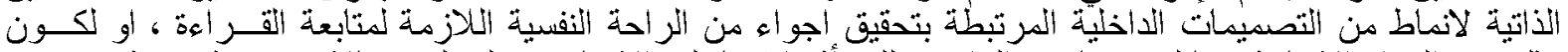

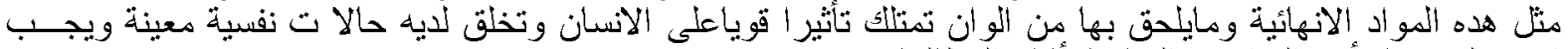
ان توظف بما يأمن التركيز و المتابعة أثناء المطالعة.

- اما ما تبقى من المتغيرات التصميمية قيد الدزاسـة فلم يكن نها تاثير يذكر في تفسير مؤشر الكفاءة كعلاقة ارتباط

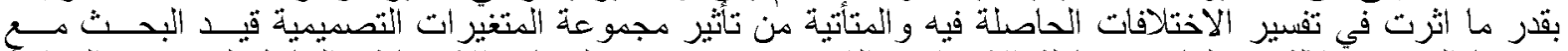

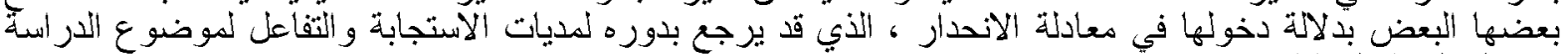

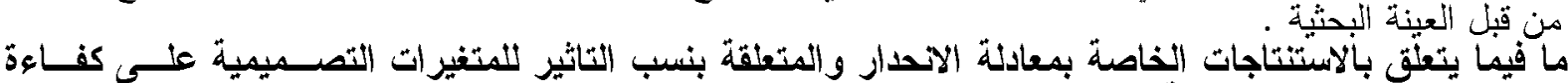

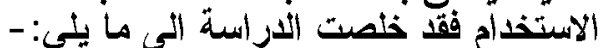

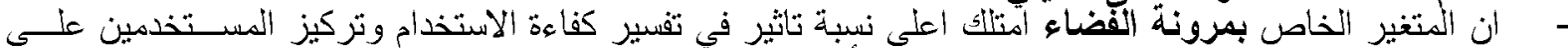

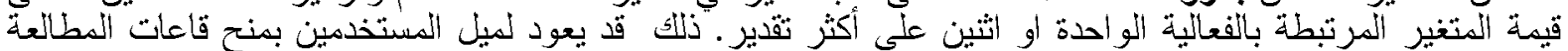

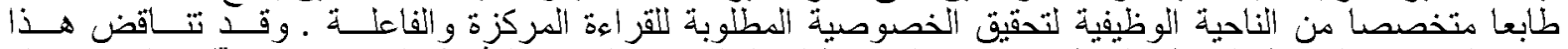

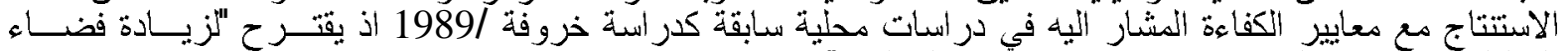

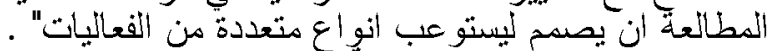

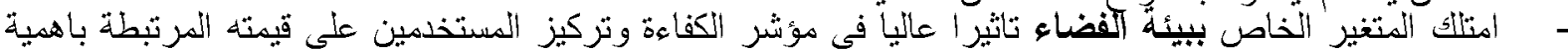

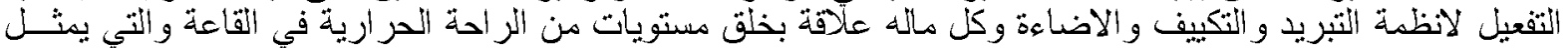

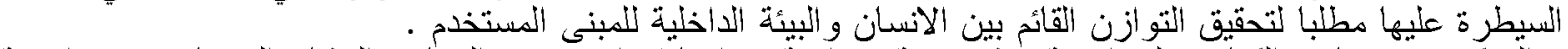

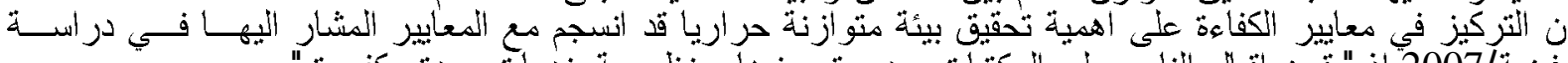

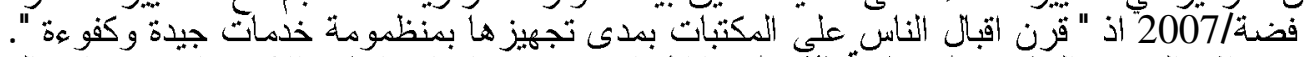

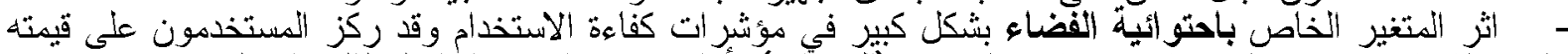

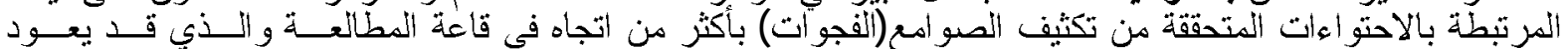

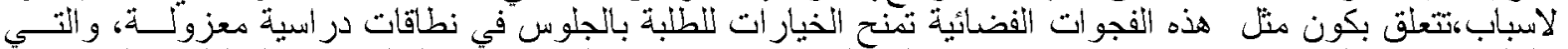

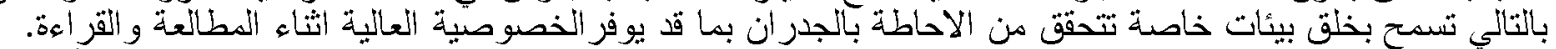

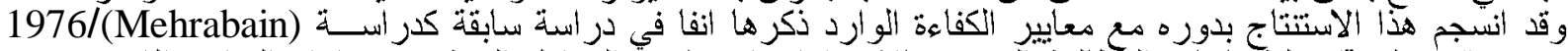

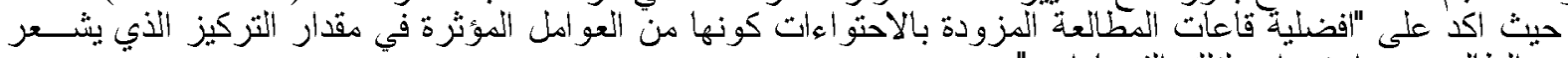

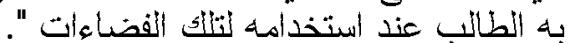

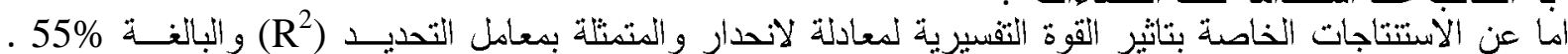

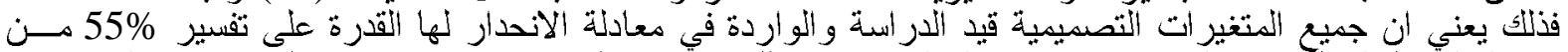

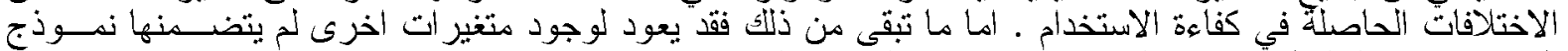
البحث وان امكانية التقصي عنها قد تثوفر في دراسات لاحتة لاحتة.

\section{خلاصة الاستنتاجات النهائية الترو}

1 - وفرت الأزاسة امكانية التوصل التي التصميم الاكثر ملانمة لقاعات المطالعة في المكتبات الجامعية من خلاتل

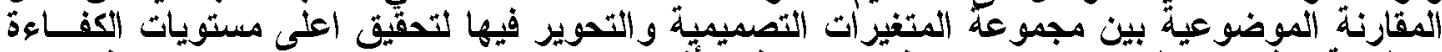

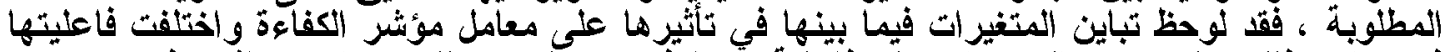

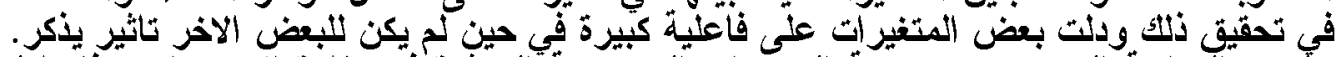

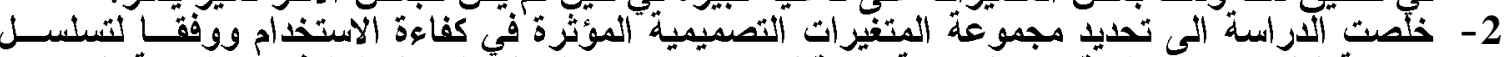

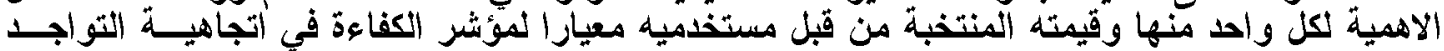

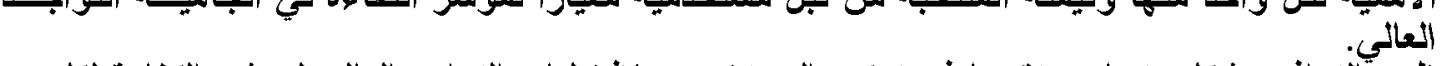

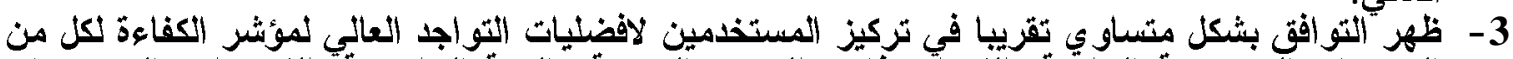

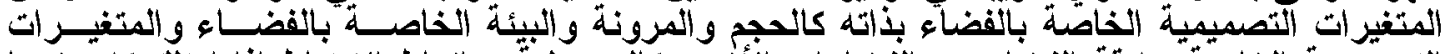

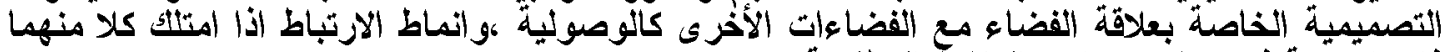

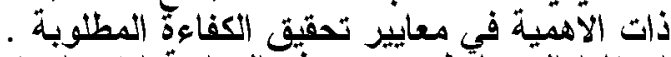

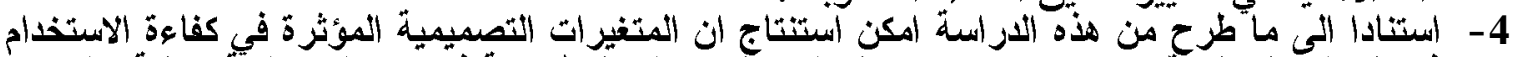

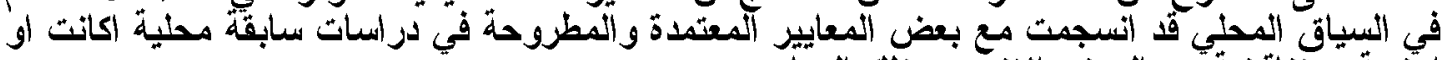

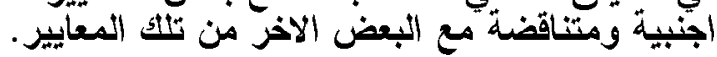


التوصيات الستثمار ما امكن التوصل اليه في هذا المجال البحثي من آطر نظرية وعلية في مجال ممارسة المهنة و التثركيز فـي

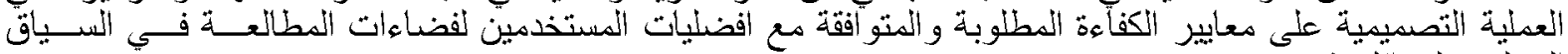

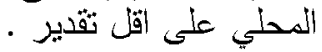

1) فنتحي عبد هادي ، محمد ، المعلومات وتكنولوجيا المعلومات على أعقاب قرن جديد ، القاهرة ، مكتبة الــدار

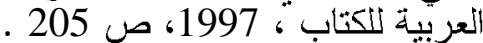

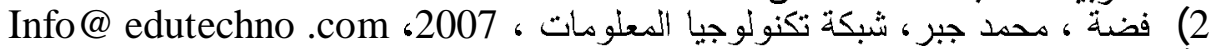

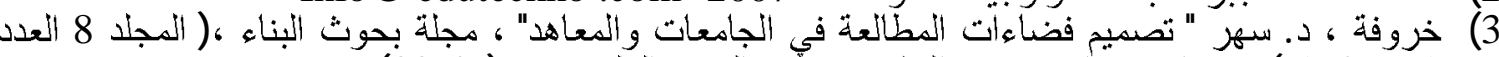

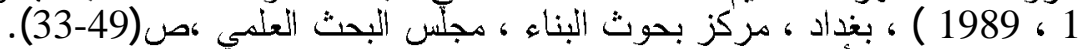

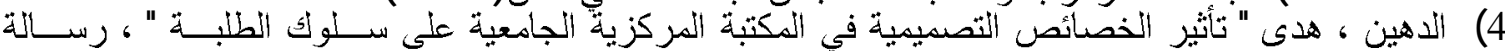

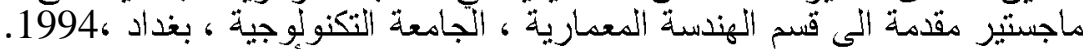

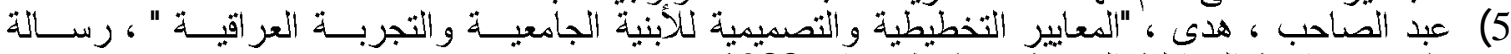

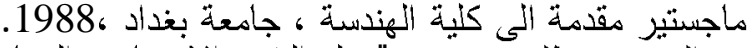

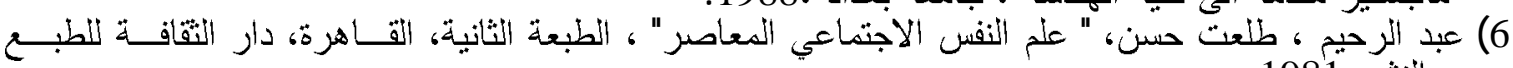

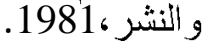

1- Loren , B.W; Libraries ; in Plamg ," The Architects hand book ; Edited by Edward D. Mills ; , 10 edition, London ; Batter Worth's ; 1985).

2- Robinowitz; " Postoccvpancy Evaluation" ; in "Introduction to Architecture" , Edited by T.c Synder ; by Mc Gtaw- Hill, Inc. New York, 1979.

3- Langmead Stephan; Beckman, Margaret; "New Library Design" ;Guide Lines to planning Academic Library Buildings"; New York; John Wiley \& Sons; 1970.

4- Canter , David; " Designing For Therapeutic Environments " ; a Review of Research ; New York: Jojn Wiley \& Sons, Ltd ; 1979.

5- Moore , Gray t. ; " Environment- Behavior Studies "; in Introduction to Architect nre " Edited by T.C Synder, A.,J .Catanese; New' York; McGraw Hill Inc.; 1979.

6- Metcalf , Keyes D.; "Planning Academic and Research Library Buildings" ; New York : Mc Graw Hill Book Company ; 1965.

7- Hall , Edward T.; "Meeting Mans Basic Spatial Needs in Artificial Environment " in Designing For Human Behavior "Edition by Jon Lang ; Pennsylvania : Dowden, Hutchinson \& Ross Inc.; 1974.

8- Sommar, Robert; "Personal Space;" The Behavioral Basis of Design; New Jersey ; Prentice Hall International, Inc. ; 1969. 9- Bendar, Michael J.; "Barrier- Free Environment" ; Pennsylvania Dowden , Hutehins \&

10- Zeisel ,John; "Inquiry by Design"; Tools for EnvironmentCambridge: Cambridge University Press; 1986.

Behavior Research;

11- Ching, Francis D.K; "Architecture : Space, Form \& Order" ; New York Van No strand Rein bold Company; Inc ; 1979.

12- Orr, J.M." Designing Library Buildings For Activities "; London : Andre Deutsh Limited 1975 .

13- University Of Bath : " The Proposed University of Bath A Technical University " Development Plan, Report No. 1 by Collin Clap LTD, England , 1965.

14- Cohen , Aaron; Cohen Elaine; " Designing and Space Planning For Libraries "; A behavioral Guide; New York \& London ; R.R Bow Ker Co.; 1979.

15- Metcalf, Keyes D.; " Furniture and Equipment: Size, Spacing and Arrangement" ; in " Reader on the Library Building "; Reader Series un Library and Information Science ; Edited by Hal B. Schell; New York ; Indian Head Inc. 1975.

16- Vischer, Jaqueline C.; Environmental Quality in Offices "; New York : Van Nostrand Reinhold; 1989. 
17- Patterson , Miles L.; Schaefler, Gerald H. ; " Studing Preferences Behavior and Design, Book 2 "Session Summaries and Papers 1 GDRA7 ; Edited by Peter Suedfeld \& James A Russel ; EDRA, Inc.; 1977.

18- Mehrabian, Albert; "Public Places and Private Spaces "; The Psychology of Work, Play, and Living Environment ; New York: Basic Books Inc.; Publishers ; 1976.

19- Bently ,A. ; ALcock , A.; Murrain, P.; " Responsive Environments " Amanual for designers ;'London ; The Architectural Press ; 1985.

20- Thompson, Godfrey ; "Planning and Design of Library Buildings "; znd Edition ; London : The Architectural Press Ltd; 1978.

21- Heimsath , Clovis ; "Behavioral Architecture " Towardan Accountable design Process; New York ; Mc Graw Hill , Inc. 1977.

22- Ferbstien , Jay ; " Observable action of activity ". JAR 3/1 January . 1974.

23- University of York " University of York - Development Plan " ; UDC. England , 1972 ,

24- Bullock, N. et. Al . "Amodel of Students daily activity Patterns " Environment and Planning m Volume 5, 1973.

25- Sannwald, William $\mathrm{W}_{\text {. }}$ " checklist of library building" ,. Design considerations,. ALA edidtion , 2009 